\title{
Review Article \\ Omega-3 Polyunsaturated Fatty Acids: The Way Forward in Times of Mixed Evidence
}

\author{
Karsten H. Weylandt, ${ }^{1,2}$ Simona Serini, ${ }^{3}$ Yong Q. Chen, ${ }^{4,5}$ Hui-Min Su, ${ }^{6}$ Kyu Lim, \\ Achille Cittadini, ${ }^{3}$ and Gabriella Calviello ${ }^{3,8}$ \\ ${ }^{1}$ Division of Medicine, Department of Hepatology, Gastroenterology and Metabolism, Rudolf-Virchow-Hospital, \\ Charité University Medicine, 13353 Berlin, Germany \\ ${ }^{2}$ Lipid Clinic, Experimental and Clinical Research Center (ECRC), Max-Delbrück-Center for Molecular Medicine and \\ Charité University Medicine, 13353 Berlin, Germany \\ ${ }^{3}$ Institute of General Pathology, Catholic University School of Medicine, 00168 Rome, Italy \\ ${ }^{4}$ The Synergistic Innovation Center for Food Safety and Nutrition, State Key Laboratory of Food Science and Technology, \\ and School of Food Science and Technology, Jiangnan University, Wuxi, Jiangsu 214122, China \\ ${ }^{5}$ Department of Cancer Biology, Wake Forest School of Medicine, Winston-Salem, NC 27157, USA \\ ${ }^{6}$ Department of Physiology, National Taiwan University College of Medicine, Taipei 100, Taiwan \\ ${ }^{7}$ Department of Biochemistry, School of Medicine, Cancer Research Institute, Infection Signaling Network Research Center, \\ Chungnam National University, Daejeon 301-747, Republic of Korea \\ ${ }^{8}$ Research Center for Biotechnology Applied to Cosmetology, Catholic University School of Medicine, 00168 Rome, Italy \\ Correspondence should be addressed to Gabriella Calviello; g.calviello@rm.unicatt.it
}

Received 21 January 2015; Revised 18 May 2015; Accepted 28 May 2015

Academic Editor: Sabine Rohrmann

Copyright (C) 2015 Karsten H. Weylandt et al. This is an open access article distributed under the Creative Commons Attribution License, which permits unrestricted use, distribution, and reproduction in any medium, provided the original work is properly cited.

Almost forty years ago, it was first hypothesized that an increased dietary intake of omega-3 polyunsaturated fatty acids (PUFA) from fish fat could exert protective effects against several pathologies. Decades of intense preclinical investigation have supported this hypothesis in a variety of model systems. Several clinical cardiovascular studies demonstrated the beneficial health effects of omega3 PUFA, leading medical institutions worldwide to publish recommendations for their increased intake. However, particularly in recent years, contradictory results have been obtained in human studies focusing on cardiovascular disease and the clinical evidence in other diseases, particularly chronic inflammatory and neoplastic diseases, was never established to a degree that led to clear approval of treatment with omega-3 PUFA. Recent data not in line with the previous findings have sparked a debate on the health efficacy of omega-3 PUFA and the usefulness of increasing their intake for the prevention of a number of pathologies. In this review, we aim to examine the controversies on the possible use of these fatty acids as preventive/curative tools against the development of cardiovascular, metabolic, and inflammatory diseases, as well as several kinds of cancer.

\section{Introduction}

Over the past three to four decades, a considerable body of literature has been published indicating possible health benefits of an increased dietary intake of long-chain omega3 polyunsaturated fatty acids (LC-omega-3 PUFA). Their beneficial effects have been reported for a number of disorders, including cardiovascular $[1,2]$, neurodegenerative $[3,4]$, neuropsychiatric $[5,6]$, and inflammatory diseases [7], as well as for some cancer types (mainly colorectal, mammary, and prostatic cancer) [8-10]. During this time period, a large number of preclinical in vitro and in vivo studies have been performed which, rather unanimously, demonstrated the potential of omega-3 PUFA as preventive and therapeutic agents against hypertriglyceridemia, cardiac arrhythmia, inflammation, and proliferation, and many experimental studies have succeeded in elucidating and clarifying many of the biological and molecular mechanisms underlying these effects [11-17]. Also, for application in humans, consensus was reached on the efficacy of these fatty acids (FA) in 
the secondary prevention of some cardiovascular diseases, since the results of a large and well performed clinical study [18] had clearly and strongly demonstrated beneficial effects linked to their intake. As a consequence, omega-3 PUFA have been approved as preventive and therapeutic tools in the management of several cardiovascular disorders, as well as for treatment of severe hypertriglyceridemia by a number of health agencies throughout the world, and a number of guidelines were published recommending omega3 PUFA supplementation (see Section 3). Cardiologists and other physicians began to prescribe them routinely [19]. Moreover, as diet has always been an important topic for the popular press, recommendations have reached large segments of population, so that over-the-counter omega-3 PUFA supplements have become the most sold supplements worldwide [20].

In contrast to this remarkable story of research performance and dissemination, many human studies investigating the effect of an increased intake of omega-3 PUFA against noncardiovascular diseases were often not in keeping with data obtained in preclinical studies, and therefore consensus recommendations have not yet been made regarding the usefulness of omega-3 PUFA for the cure or prevention of inflammatory, neoplastic or neurologic disorders.

Some reports question the effectiveness of omega-3 PUFA in cardiovascular prevention [21-24], and others argue that an increased intake of these compounds could induce or exacerbate some neoplastic pathologies [25-27]. Where does this leave the field of omega-3 PUFA research and application? We will try to address this pertinent question exploring in Section 2 our body's need for omega-3 PUFA to satisfy physiological needs and to prevent the development of several kinds of diseases, in Section 3 the history and present status of omega-3 PUFA in cardiovascular diseases, in Section 4 inflammatory diseases, and in Section 5 colorectal and prostate cancer. We will describe in each of these sections the controversies arisen, and in Section 6 we will consider and critically analyze all the possible reasons for these discrepancies.

\section{Omega-3 PUFA Insufficiency/Deficiency and Current Recommended Intakes}

Alpha-linolenic acid (ALA), an 18-carbon omega-3 essential $\mathrm{FA}$, is the precursor of eicosapentaenoic acid (EPA) and docosahexaenoic acid (DHA). The term "essential" indicates that ALA cannot be synthesized by humans and therefore must be entirely acquired from exogenous sources. Evidence for the essentiality of ALA was first provided by a study showing that ALA supplementation reversed the abnormal neurologic signs observed in a 6-year-old girl who suffered from sensory loss and visual complications [28]. Following consumption, most of the ALA is catabolized via $\beta$-oxidation for energy generation, and a small proportion of it undergoes conversion to produce another two potent members of omega-3 PUFA family: EPA and DHA [29]. The conversion rates of ALA to EPA and DHA in humans are estimated at $8-20 \%$ and $0.5-9 \%$, respectively [30]. Owing to the fact that
EPA and DHA can be synthesized in the body from ALA, these two FA do not meet the definition of essential FA per se. However, as this conversion is not efficient enough to satisfy health requirements, EPA and DHA are also considered essential FA (or conditionally essential FA). In addition, although not conclusive, the benefits associated with ALA seem to stem mainly from EPA and DHA, and as major consequence of ALA deficiency it appears that EPA and DHA are not adequately produced [31, 32]. The clinical features of omega-3 PUFA insufficiency include impaired growth, skin lesions, infertility, kidney abnormalities, fatty liver, polydipsia, increased susceptibility to infections, reduced learning, and impaired vision $[33,34]$. Yet, these symptoms are nonspecific and may also result from the dysregulation in omega-6 PUFA homeostasis [35]. For example, the skin lesions present in patients with atopic eczema have been associated with poor omega-6 PUFA intake [36].

An increased intake of omega-3 PUFA, especially the long-chain omega-3 PUFA EPA and DHA, could reduce the tissue omega-6/omega-3 ratio to a level that probably existed during millions of years of human evolution [37]. This ratio dramatically increased in recent millennia due to deep changes in dietary habits following the transition from the hunter-gatherer lifestyle to agricultural societies. This change could therefore be one of the crucial factors leading to the rise of the so-called diseases of civilization, further skewed towards omega-6 PUFA by the agricultural revolution in the 19th century and the massive use of corn (with its high omega-6 PUFA content) in western societies during the 20th century.

Dietary recommendations for omega-3 PUFA, previously focused on ensuring their sufficient intake to prevent deficiency, are increasingly seeking to define an "optimal" intake to reduce the risk of developing chronic diseases, in particular cardiovascular diseases (CVD). To date, there is no uniform scientific guideline on the ideal omega-3 PUFA intake. Nutritional guidelines have been published by several governments (France, Belgium, Netherlands, New Zealand, and Australia) and health organizations (Food and Agriculture Organization (FAO), American Dietetic Association). The most popular recommendations on omega-3 PUFA intake are those published by the American Heart Association (AHA), the UK Committee on Medical Aspects of Food Policy, the World Health Organization (WHO), and the European Food Safety Authority (EFSA). Recommendations for omega-3 PUFA (ALA, EPA, and DHA, individually or combined) for adults according to various recently published dietary guidelines are shown in Table 1, whereas Table 2 shows recommendations for infants and children [38-53]. Dietary recommendations for EPA + DHA range from 250 to $1000 \mathrm{mg} /$ day for adults and from 40 to $250 \mathrm{mg} /$ day for infants older than six months and for children and adolescents.

\section{Omega-3 PUFA Efficacy in the Cardiovascular Field}

The predominant field of omega-3 PUFA research in the past decades has been that of cardiovascular medicine and 
TABLE 1: Recommended dietary intakes for omega-3 fatty acids in adults from national and international organizations.

\begin{tabular}{|c|c|c|c|c|}
\hline Region/country & Organization, year, reference & ALA (g/day) & DHA (g/day) & $\mathrm{EPA}+\mathrm{DHA}$ (g/day) \\
\hline \multirow{5}{*}{ International } & FAO/WHO, 2010 [38] & & & $0.25-2.0$ \\
\hline & ISSFAL, 2004 [39] & & & $>0.5$ \\
\hline & Eurodiet, $2001[40]$ & 2.0 & & 0.2 \\
\hline & WAPM, 2008 [41] & & $0.2-0.3$ & \\
\hline & EFSA, $2010[42]$ & & & 0.25 \\
\hline \multicolumn{5}{|l|}{ National } \\
\hline UK & SACN, $2004[43]$ & & & 0.45 \\
\hline Netherlands & Health Council, 2006 [44] & & & 0.45 \\
\hline France & ANSES, $2001[46]$ & & 0.25 & 0.5 \\
\hline Spain & SENC, $2011[48]$ & & & $0.5-1.0$ \\
\hline Australia & NHMRC, 2006 [49] & $\begin{array}{l}\text { M: } 1.3 \\
\text { F: } 0.8\end{array}$ & & $\begin{array}{l}\text { M: } 0.61 \\
\text { F: } 0.43\end{array}$ \\
\hline \multirow{4}{*}{ USA } & IoM, $2005[50]$ & $\begin{array}{c}\text { M: } 1.6 \\
\text { F: } 1.1\end{array}$ & & \\
\hline & American Diabetes Association, 2007 [51] & 2.0 & & 0.2 \\
\hline & ADA USA \& Canada, 2007 [52] & $\begin{array}{c}\text { M: } 1.6 \\
\text { F: } 1.1\end{array}$ & & 0.5 \\
\hline & AHA, $2009[53]$ & & & $0.5-1.0$ \\
\hline
\end{tabular}

M: male; F: female.

TABLE 2: Recommended dietary intakes for omega-3 fatty acids in children from national and international organizations.

\begin{tabular}{|c|c|c|c|c|c|}
\hline Region/country & Organization, year & Age range & ALA (mg/day) & DHA (mg/day) & $\mathrm{EPA}+\mathrm{DHA}$ (mg/day) \\
\hline \multirow{6}{*}{ International } & \multirow{4}{*}{ FAO/WHO, 2010 [38] } & $6-24 \mathrm{mo}$ & & $10-12 / \mathrm{kg}$ & \\
\hline & & $2-4 y$ & & & $100-150$ \\
\hline & & $4-6 y$ & & & $150-200$ \\
\hline & & $6-10 y$ & & & $200-250$ \\
\hline & \multirow{2}{*}{ EFSA, $2010[42]$} & $7-24 \mathrm{mo}$ & & 100 & \\
\hline & & 2-18y & & & 250 \\
\hline \multicolumn{6}{|l|}{ National } \\
\hline Belgium & CSS, 2009 [47] & $0-12 \mathrm{mo}$ & 500 & & \\
\hline \multirow{2}{*}{ Netherlands } & \multirow{2}{*}{ Health Council, 2001 [45] } & $0-5 \mathrm{mo}$ & $80 / \mathrm{kg}$ & $20 / \mathrm{kg}$ & \\
\hline & & $6 \mathrm{mo}-18 \mathrm{y}$ & & & $150-200$ \\
\hline \multirow{3}{*}{ France } & \multirow{3}{*}{ ANSES, 2001 [46] } & $6 \mathrm{mo}-3 \mathrm{y}$ & & 70 & \\
\hline & & $3-9 y$ & & 125 & 250 \\
\hline & & $10-18 y$ & & 250 & 500 \\
\hline \multirow{4}{*}{ Australia } & \multirow{4}{*}{ NHMRC, 2006 [49] } & $1-3 y$ & 500 & & 40 \\
\hline & & $4-8 y$ & 800 & & 55 \\
\hline & & $9-13 y$ & $\begin{array}{c}\text { M: } 1000 \\
\text { F: } 800\end{array}$ & & 70 \\
\hline & & $14-18 y$ & $\begin{array}{c}\text { M: } 1200 \\
\text { F: } 800\end{array}$ & & $\begin{array}{l}\text { M: } 125 \\
\text { F: } 85\end{array}$ \\
\hline \multirow{4}{*}{ USA } & \multirow{4}{*}{ IoM, 2005 [50] } & $1-3 y$ & 700 & & \\
\hline & & $4-8 y$ & 900 & & \\
\hline & & $9-13 y$ & $\begin{array}{c}\text { M: } 1200 \\
\text { F: } 1000\end{array}$ & & \\
\hline & & $14-18 y$ & $\begin{array}{l}\text { M: } 1600 \\
\text { F: } 1100\end{array}$ & & \\
\hline
\end{tabular}

M: male; F: female. 
prevention. This is the field in which the hypothesis of a protective effect of omega-3 PUFA was founded [69], and a large clinical study establishing a benefit was the basis for approval of omega-3 PUFA as secondary prevention in patients after myocardial infarction [18]. The GISSI-Prevenzione trial was performed as an open-label trial in the 1990s in 11324 patients shortly after myocardial infarction. Participants in the omega-3 PUFA group received $1 \mathrm{~g} / \mathrm{d}$ omega-3 PUFA (ratio of EPA/DHA 1:2, with a total amount of EPA + DHA of approximately $850 \mathrm{mg}$ ) for 3.5 years. There were no systematic fatty acid measurements performed in the participants, but, as an indication of omega-3 PUFA uptake, triglycerides were lower in the omega-3 PUFA group. Treatment with omega3 PUFA significantly lowered the risk of death, including cardiovascular death [18]. This area has seen some good examples of translational research, particularly with regard to the antiarrhythmic effects attributed to omega-3 PUFA. Leaf $[70,71]$ was a pioneer in the field of omega-3 PUFA research showing that these FA can block proarrhythmogenic effects of adrenal agents, calcium, and other substances in isolated cardiomyocytes, continuing with studies in animals [72], and finally concluding his research in a large human multicenter trial [54]. The concept of cardioprotection through omega3 PUFA supplementation has been firmly engrained into the canon of medical knowledge and clinical thinking, as is evidenced by the AHA guidelines recommending intake of omega-3 PUFA [73].

However, while preclinical data regarding the antiarrhythmic effect of omega-3 PUFA were strongly beneficial, the double-blind intervention study by Leaf et al. [54] does not show a clear benefit. A relevant problem of the study was the high noncompliance rate (35\% of enrollees, similar in fish oil and olive oil groups), probably due to the high capsule load (2600 mg fish oil per day). Treatment with daily fish oil or olive oil for 12 months in patients with implanted cardioverter/defibrillators (ICDs) did not lead to a significant difference for the primary end point (time to first ICD event for ventricular tachycardia (VT) or death from any cause). However, there was a significant effect in participants who were at risk of fatal ventricular arrhythmias and, after staying on protocol for at least 11 months, showed a significant risk reduction of $38 \%$. Phospholipid fatty acid content of red blood cells was compared in a subset of participants in the study, and omega-3 PUFA content increased significantly from $3.4 \%$ to $7.6 \%$ of total fatty acids, while it remained at $3.5 \%$ in the olive oil control group.

There are two more randomized, double-blind, placebocontrolled trials with omega-3 PUFA supplementation performed in patients with ICDs and at high risk of high-grade arrhythmic events. In one, 200 patients with an ICD and a recent episode of sustained VT or ventricular fibrillation (VF) received either $1300 \mathrm{mg} / \mathrm{d}$ omega-3 PUFA or placebo and were followed up for 2 years. While patients on fish oil had an increase in the mean percentage of omega-3 PUFA in red blood cell membranes from $4.7 \%$ at baseline to a steadystate maximum of $8.3 \%$ at 3 months, there was no protection from VT/VF events [59]. The third study did not find a significant advantage for omega-3 PUFA supplementation in ICD patients receiving $2 \mathrm{~g} / \mathrm{d}$ of fish oil $(n=273)$ versus placebo $(n=273)$ for one year with the primary outcome of an ICD event or death occurring in 30\% patients taking omega-3 PUFA versus $33 \%$ of those on placebo [60].

In addition to these high-quality data sets showing uncertainty regarding the antiarrhythmic effect of omega-3 PUFA, several large studies followed up on the initial positive GISSI-P results. The GISSI-HF investigated the effect of $1 \mathrm{~g} / \mathrm{d}$ omega-3 PUFA in patients with heart failure in a randomised, double-blind, placebo-controlled trial with 6975 participants. Over approximately 4 years there was a small significant advantage in the omega-3 PUFA group for death from any cause and admission to hospital for cardiovascular reasons with a number needed to treat of 56 to prevent one death [55].

A multicenter, double-blind, placebo-controlled trial with 4837 patients after a myocardial infarction tested 40 months of fatty acid supplementation in the form of margarines, either adding a small amount of approximately $400 \mathrm{mg} / \mathrm{d} \mathrm{EPA}+\mathrm{DHA}, 2 \mathrm{~g} / \mathrm{d}$ of ALA, both EPA + DHA and ALA, or placebo fat. Neither EPA-DHA nor ALA reduced the primary end point of a major cardiovascular event. Fatty acids were measured in plasma cholesteryl esters of subgroups, and supplementation with EPA + DHA increased EPA by $53.3 \%$ and DHA by $28.6 \%$, as compared with placebo after 20 months. Unfortunately, fatty acid composition of red blood cell membranes was not measured in this study [21].

Another randomized, placebo-controlled, double-blind, multicenter trial in 3851 patients with $1 \mathrm{~g} / \mathrm{d}$ omega-3 PUFA supplementation for one year in patients after acute myocardial infarction also demonstrated no benefit of omega-3 PUFA [58].

A third large study with 2501 participants found that administration of $600 \mathrm{mg} / \mathrm{d}$ omega-3 PUFA increased plasma concentrations of EPA + DHA by $37 \%$ compared with placebo but also had no significant effect on major vascular events in patients with ischaemic heart disease or ischaemic stroke [56].

Based on these and several smaller intervention studies assessing mostly relatively low-dose omega-3 PUFA supplementation, two thorough metastudies concluded that there is no convincing evidence for a preventive effect of omega-3 PUFA in patients with cardiovascular disease $[22,62]$.

The ORIGIN study [23] is the most recent large study that failed to show a clear benefit of omega-3 PUFA supplementation for cardiovascular health. This study, conducted in a patient population with dysglycemia, led many physicians to conclude that the relationship between dietary omega- 3 and cardiovascular health needs to be viewed with caution. In this double-blind study 12536 dysglycemic patients at high risk for cardiovascular events were assigned to either $900 \mathrm{mg} / \mathrm{d}$ omega-3 PUFA or placebo. The primary outcome was death from cardiovascular causes during a median follow-up of 6.2 years, and there were no significant differences between the two treatment groups for this primary parameter as well as for a range of secondary parameters. It is noteworthy that the significant decrease of triglycerides is an indicator of effective omega-3 PUFA exposure in the verum group. However, unfortunately, fatty acid levels in the blood, particularly in the red blood cell fraction, were not evaluated. 
Nutritional research, especially the clinical trials investigating different dietary regimes, has always been surrounded by controversy. The role of dietary fat in obesity and associated clinical conditions is a prime example [74], with ongoing uncertainty about the role of a low-fat diet in the battle against cardiovascular disease [61]. Recent recommendations by the AHA and the medical bodies in the US acknowledged also a protective effect of the omega-6 PUFA [53], and more studies have added complexity and controversy to the role of different FA classes (saturated fats, monounsaturated olive oil, polyunsaturated omega-6, and omega-3 PUFA), challenging not only the hypothesis of beneficial effects associated with unsaturated fatty acids but also the paradigm of the damaging effects of saturated fatty acids $[61,75]$.

What can we learn from all this regarding the potential cardiovascular benefits of omega-3 PUFA? It is difficult from today's perspective to adequately assess the conditions of the 70s observations regarding the omega- 3 effects in the Greenland population, and the arguments of inadequate data validity in these studies made by Fodor et al. [24] are plausible giving the remoteness of many Greenland communities and problems with medical service and adequate documentation in these areas.

While the protective cardiovascular effect of omega-3 PUFA was not detected in several large recent high-quality studies, there are particularly two high-quality intervention studies, both of them open-label studies though, showing a clear benefit of omega-3 PUFA, the GISSI-P study [18] and the JELIS study demonstrating a protective effect of an EPA preparation combined with a statin medication [57]. This large open-label study performed on 18645 Japanese patients assigned them to randomly receive either $1800 \mathrm{mg} / \mathrm{d}$ of EPA daily plus statin or statin only. The primary endpoint of a major coronary event was significantly reduced in the EPA group with a $19 \%$ relative reduction. However, sudden cardiac death and coronary death did not differ between the groups. Plasma EPA was measured in this study and in patients still on supplement after 5 years of observation plasma EPA concentration was increased by $70 \%$ in the EPA group.

In conclusion, many high-quality preclinical (observational as well as interventional) and clinical studies have been performed to assess the potential cardiovascular benefit of omega-3 PUFA. A recent large metastudy has again analyzed and summarized these studies and found no clear benefit of omega-3 PUFA to protect from coronary artery disease in observational studies as well as in randomized, controlled trials [61]. This metastudy also explored the role of other fatty acids and concluded that the current evidence does not clearly support cardiovascular guidelines encouraging either high consumption of omega-3 or omega-6 PUFA, or even low consumption of saturated fats.

Cardioprotective effects of dietary omega-3 PUFA might be confounded by the use of cholesterol-lowering medications: in the GISSI-P study only $5 \%$ of participants were on a cholesterol-lowering drug [18], which is in strong contrast to the ORIGIN omega-3 PUFA study, where approximately half the patients were on a statin [23]. Statins have been hypothesized to interfere with the protective effect of omega3 PUFA [76].
Modifications in the observed omega-3 effects might also be due to changes in the diet over the last 30-40 years, in which the hypothesis of omega-3 PUFA as beneficial dietary components has been propagated, and therefore background levels of omega-3 PUFA in the participants of more recent studies might be higher than several decades ago. This should be addressable by (comparable) measurements of omega-3 PUFA that, unfortunately, have been performed only sporadically in the studies carried out to date. Baseline omega-3 PUFA levels are lacking from most of the discussed large studies investigating omega-3 PUFA interventions. Several studies have suggested that erythrocyte EPA and DHA content (measured by a certified method as "omega-3 index") may better reflect the omega-3 PUFA status in patients than measurement in plasma and white blood cells $[77,78]$, and the low omega-3 index was described to be associated with higher mortality in patients with cardiovascular disease. However, so far, there has been no single well-accepted and uniformly performed blood test for the omega-3 PUFA status in human studies, complicating the comparison and interpretation of different studies. The current state of evidence for the effects of omega-3 PUFA in human studies regarding cardiovascular diseases and the contrasting outcomes have been summarized in Table 3. Additional possible reasons for the controversies in the field are reported in Section 6.

Last but not least, it should be noted that the effect of omega-3 PUFA in the cardiovascular field can also be viewed in the context of their role as precursors of highly potent physiologically beneficial lipid mediators $[79,80]$. A cytochrome P450 epoxygenase-dependent metabolite of EPA, namely, $17(R), 18(S)$-epoxyeicosatetraenoic acid $(17(R), 18(S)$-EETeTr), was found to exert negative chronotropic effects and can protect neonatal rat cardiomyocytes against $\mathrm{Ca} 2+$-overload [81]. Another EPA-metabolite, 18-hydroxyeicosapentaenoic acid (18-HEPE), was recently shown to inhibit macrophagemediated proinflammatory activation of cardiac fibroblasts in vitro, while in vivo administration of 18-HEPE led to resistance to pressure overload-induced maladaptive cardiac remodeling in mice [82].

\section{Omega-3 Efficacy in Inflammatory Diseases}

Research data accumulated to date indicate that omega- 6 PUFA play a significant role in the biology of inflammation. Work on the biochemistry of omega- 6 led to the identification of prostaglandins and leukotrienes as key players in the physiology of inflammation [118]. Moreover, this work elucidated the cascade of the molecular mediator system arising from the omega-6 PUFA arachidonic acid and led to mechanistic understanding and further development of the most widely prescribed drug class worldwide, the cyclooxygenase(COX-) inhibitors [119].

Early work on omega-3 PUFA identified the antagonism between omega- 6 and omega- 3 PUFA. It was postulated that, by competitive inhibition of COX and other enzymes, omega3 PUFA could serve as anti-inflammatory agents. Indeed, it has been found that a high omega- 3 intake was associated with a lower risk of inflammatory disease mortality [120]. 
TABLE 3: Current state of evidence for the effects of omega-3 PUFA in published human intervention studies regarding cardiovascular disease.

\begin{tabular}{|c|c|c|c|c|}
\hline Type of study & Beneficial effect & $\begin{array}{l}\text { Beneficial effect limited to } \\
\text { subpopulation }\end{array}$ & $\begin{array}{l}\text { Detrimental } \\
\text { effect }\end{array}$ & No effect \\
\hline \multirow{6}{*}{ Clinical trials } & $\begin{array}{l}\text { Lower risk of } \\
\text { cardiovascular events and } \\
\text { death with open-label } \\
\text { omega-3 PUFA treatment } \\
(850 \mathrm{mg} / \mathrm{d})[18]\end{array}$ & $\begin{array}{l}\text { High-dose omega-3 PUFA } \\
\text { intervention in ICD } \\
\text { patients at high risk of } \\
\text { arrhythmia-significant } \\
\text { protection in patients } \\
\text { treated per protocol for } 11 \\
\text { months [54] }\end{array}$ & & $\begin{array}{l}\text { Administration of } 900 \mathrm{mg} / \mathrm{d} \text { omega-3 } \\
\text { PUFA in dysglycemic patients at } \\
\text { increased cardiovascular risk had no } \\
\text { protective effect [23] }\end{array}$ \\
\hline & $\begin{array}{l}\text { Lower risk of death in } \\
\text { patients with heart failure } \\
\text { on } 1 \mathrm{~g} / \mathrm{d} \text { omega-3 PUFA } \\
{[55]}\end{array}$ & & & $\begin{array}{l}\text { No decrease in major cardiovascular } \\
\text { events in patients on } 500 \mathrm{mg} / \mathrm{d} \\
\text { omega-3 PUFA [56] }\end{array}$ \\
\hline & $\begin{array}{l}\text { Cardioprotective effect of } \\
\text { open-label EPA } \\
\text { supplementation in } \\
\text { addition to a statin in } \\
\text { hypercholesterolemic } \\
\text { patients [57] }\end{array}$ & & & $\begin{array}{l}\text { Administration of } 1 \mathrm{~g} / \mathrm{d} \text { omega- } 3 \text { PUFA } \\
\text { in patients after a myocardial } \\
\text { infarction showed no benefit }[58]\end{array}$ \\
\hline & & & & $\begin{array}{l}\text { No reduction in cardiovascular events } \\
\text { in patients after myocardial infarction } \\
\text { with either } 400 \mathrm{mg} / \mathrm{d} \text { EPA + DHA or } \\
2 \mathrm{~g} / \mathrm{d} \text { ALA, or both [21] }\end{array}$ \\
\hline & & & & $\begin{array}{l}\text { No VT/VF protection in ICD patients } \\
\text { on } 1300 \mathrm{mg} / \mathrm{d} \text { omega-3 PUFA [59] }\end{array}$ \\
\hline & & & & $\begin{array}{l}\text { No arrhythmia protection in ICD } \\
\text { patients on } 2 \mathrm{~g} / \mathrm{d} \text { fish oil [60] }\end{array}$ \\
\hline \multirow{3}{*}{ Meta-analyses } & & & & $\begin{array}{l}\text { Current data do not support the } \\
\text { concept of increasing omega-3 PUFA } \\
\text { or omega-6 PUFA or decreasing } \\
\text { saturated fatty acid intake, to reduce } \\
\text { cardiovascular risk [61] }\end{array}$ \\
\hline & & & & $\begin{array}{l}\text { No benefit of omega-3 PUFA } \\
\text { supplementation in } 14 \text { randomized } \\
\text { double-blind placebo-controlled } \\
\text { studies [22] }\end{array}$ \\
\hline & & & & $\begin{array}{l}\text { No benefit of omega-3 PUFA } \\
\text { supplementation in randomized } \\
\text { clinical trials assessing cardiovascular } \\
\text { endpoints [62] }\end{array}$ \\
\hline
\end{tabular}

ICD: implanted cardioverter/defibrillator; VF: ventricular fibrillation; VT: ventricular tachycardia.

Many animal studies demonstrated the anti-inflammatory effect of omega-3 PUFA. As far as animal models of colitis are considered, EPA-ethyl or DHA-ethyl ester supplementations $(1 \% \mathrm{w} / \mathrm{w}$ in the diet, given for 10 days prior to treatment) were reported to reduce colitis obtained in dextran sodium sulfate- (DSS-) treated mice [121], as demonstrated by their ability to inhibit the expression of several proinflammatory cytokines. Similar results were obtained also by supplementing a FO enriched diet (concentration not specified, dietary n:6/n:3 ratio: 1.5 , for $7-11$ weeks) in a severe combined immunodeficient mouse model of colitis [122]. In agreement with that, a FO enriched diet (containing $1 \%$ FO providing $0.5 \mathrm{~g} \mathrm{EPA}+\mathrm{DHA} \mathrm{g} /$ day, for 5 weeks prior to infection) was shown to attenuate infection-induced colitis in mouse infected with Citrobacter [123]. Furthermore, also a parenteral lipid emulsion enriched in omega-3 PUFA (10\% FO, $0.5 \mathrm{~mL} / \mathrm{h}$ for 7 days) was found to reduce acetic acidinduced colitis in rats [124].

However, opposite results have also been obtained and extensively and recently reviewed by Fenton et al. [125]. In particular, dietary FO $(8 \% \mathrm{w} / \mathrm{w}$ in the diet, for 5 weeks, starting one week prior to treatment) was shown to increase DSS-induced colitis [126]. Moreover, diets containing 2.25$6.00 \%$ FO (containing 59\% DHA + EPA, for 8 weeks after infection) were recently found to induce severe colitis and epithelial dysplasia in mice infected with Helicobacter hepaticus [127]. Furthermore, FO (7\% FO w/w in the diet, for 12 weeks) was found to exacerbate colitis and colitisassociated premalignant lesions [128] in IL-10 -/- transgenic mice, spontaneously developing enterocolitis [129]. 
In contrast, Chapkin et al. [130] showed that a FO enriched diet ( $4 \% \mathrm{FO} \mathrm{w} / \mathrm{w}$ in the diet, for 10 weeks) fed to the same IL-10 -/ - transgenic mice reduced the clinical score of both spontaneous and NSAID-induced colitis.

Interestingly, however, when at least the uncertainty related to variable intakes of FO was overcome by using the Fat-1 mouse model of endogenously increased omega3 PUFA [131], the inflammation-dampening effect of an increased omega-3 PUFA tissue content was consistently observed in the murine models of DSS-induced colitis [132, 133]. Moreover, when Fat-1 mice were also treated with the carcinogen azoxymethane prior to DSS, an enhanced ability to resolve colitis and a reduced number of colonic adenocarcinomas per mouse were observed $[134,135]$. In the Fat-1 mouse model a reduced D-galactosamine/lipopolysaccharide- (DGalN/LPS-) induced hepatitis [136] and cerulein-induced pancreatitis [137] were also observed.

As concluded by Fenton et al., it is particularly in the context of studies with infectious agents that deleterious effects of omega-3 PUFA were observed [125], and these authors argue that the same (auto)inflammation-dampening and cardioprotective properties of the omega-3 PUFA might be responsible for an ineffective immune response against pathogens and even decreased immune surveillance against tumor cells. However other data do not support this view of a uniformly immunosuppressant effect of omega-3 PUFA: a recent study shows that omega-3 PUFA can actually increase B-cell function and thus humoral immunity [138].

Also the clinical data from intervention trials with omega-3 appear to be controversial. Initial results in Crohn's disease and ulcerative colitis $[63,66]$ found a benefit. However, later studies showed a negligible impact of omega-3 PUFA on the relapse rate in Crohn's disease [65] as well as in ulcerative colitis; the studies performed in inflammatory bowel disease are reviewed in a recent metastudy, concluding that total data quality so far is insufficient for clear recommendations [68]. Data from acute pancreatitis in humans indicated some benefits [67]; however, there are no data from chronic pancreatitis, and the recently published Welcome Trial data regarding the use of omega-3 PUFA in nonalcoholic steatohepatitis (NASH) do not show an overwhelming benefit of supplementation in the intentionto-treat (ITT) analysis, even though there was a statistically significant linear correlation between decreased liver fat content and increased DHA enrichment [64]. The current state of evidence for the effects of omega-3 PUFA in human studies regarding inflammatory diseases and the contrasting outcomes have been summarized in Table 4. Possible reasons for the controversies in the field are reported in Section 6.

Experimental data from recent years are currently reshaping omega-3 PUFA research: since the initial description of resolvins [139] and the characterization of resolvin E1 [140], a wealth of data on this new class of omega-3 PUFA-derived lipid mediators has been published (reviewed in [80]). It is now clear that omega-3 PUFA not only play a role as competitive antagonists of the COX and lipoxygenase (LOX) enzymes, but also are substrates for potent lipid mediators themselves. It has been shown that a high abundance of these FA as substrates can significantly change the lipidome and eicosanome, given that they are efficiently metabolized as well [79]. For the DHA-derived D-resolvins, 17-HDHA has been characterized as a central pathway precursor/metabolite, and for the EPA-derived E-resolvins, 18-HEPE serves this role. Data from one of the authors have indicated that these might have anti-inflammatory properties themselves [141143]. Other groups have described the effects of 17-HDHA as well [144-146], and very recently an independent role of 18-HEPE was also demonstrated in the context of a cardiac fibrosis model [82]. This is currently a very active field of research and will probably give us new tools for understanding the effects of omega-3 PUFA in the context of inflammation dampening, as well as a number of new leads for pharmacological compounds that could be used to mediate anti-inflammatory effects in the future. As these compounds can promote resolution of inflammation [147], this could lead to an entirely new approach to the treatment of chronic inflammation in the future.

Closely related to these effects regarding inflammation dampening are the experimental data regarding tumorigenesis. One of us and his group have validated a tumorigenesis inhibiting effect in the Fat-1 mouse model with endogenously increased omega-3 PUFA for liver cancer [143] and colon cancer [135]; this fits well with data from other groups employing the Fat-1 mouse model [134, 148, 149].

Particularly in gastrointestinal medicine, the paradigm of inflammation-associated carcinogenesis is central. It holds true for the development of esophageal carcinoma on the basis of Barrett's esophagus, stomach cancer on the basis of chronic $H$. pylori infection, liver cancer as a consequence of chronic hepatitis, cholangiocellular cancer in chronic cholangitis, pancreatic cancer as a consequence of chronic pancreatitis, and also in colorectal cancer. There are clinical data supporting the tumorigenesis inhibiting effect of omega3 PUFA in the gastrointestinal tract, either with regard to colon cancer and the lowering of polyp formation in the colon $[83,90,91]$ or with regard to hepatocellular carcinoma [150]. It is therefore conceivable that increasing omega-3 PUFA intake could be established as an easy and low-risk, highgain intervention for the prevention of tumorigenesis. Given the very low risk of severe adverse events in comparison to interventions such as the use of the COX-inhibitor aspirin, for which similar antitumorigenesis effects are well established by now [151, 152], omega-3 PUFA supplementation becomes an attractive perspective. An ongoing study is even testing the combination of EPA and aspirin for the prevention of colon polyps [153].

\section{Omega-3 Efficacy in Cancer}

5.1. Mechanisms Involved in Omega-3 PUFA Anticancer Action. Most of the studies performed either in vitro or using animal models of cancer have demonstrated the possible preventive and therapeutic role of omega-3 PUFA against several types of cancer. These studies have also shed light on multiple molecular pathways modulated by these fatty acids in cancer cells and implicated in the regulation of several cell processes involved in cancer development and progression, such as cell proliferation, survival, differentiation, 
TABLE 4: Current state of evidence for the effects of omega-3 PUFA in human studies regarding gastrointestinal inflammatory conditions.

\begin{tabular}{|c|c|c|c|c|}
\hline Type of study & Beneficial effect & $\begin{array}{l}\text { Beneficial effect limited to } \\
\text { subpopulation }\end{array}$ & $\begin{array}{l}\text { Detrimental } \\
\text { effect }\end{array}$ & No effect \\
\hline \multirow{3}{*}{ Clinical trials } & $\begin{array}{l}\text { Reduced rate of relapse with } 2.7 \mathrm{~g} / \mathrm{d} \\
\text { omega-3 PUFA in patients with } \\
\text { Crohn's disease in a double-blind } \\
\text { placebo-controlled study in } 78 \\
\text { patients [63] }\end{array}$ & $\begin{array}{l}\text { Decreased liver fat content } \\
\text { with increased DHA } \\
\text { enrichment in NASH } \\
\text { patients [64] }\end{array}$ & & $\begin{array}{l}\text { Randomized, double-blind, } \\
\text { placebo-controlled } \\
\text { treatment with approx. } \\
4 \mathrm{~g} / \mathrm{d} \text { omega-3 PUFA did } \\
\text { not prevent relapses in } \\
\text { patients with Crohn's } \\
\text { disease [65] }\end{array}$ \\
\hline & $\begin{array}{l}\text { Improvements in histologic findings } \\
\text { and weight gain in } 18 \text { ulcerative } \\
\text { colitis patients on } 5 \mathrm{~g} / \mathrm{d} \mathrm{EPA}+\mathrm{DHA} \\
\text { in a randomized double-blind } \\
\text { placebo-controlled crossover trial } \\
{[66]}\end{array}$ & & & \\
\hline & $\begin{array}{l}\text { Shortened hospital stay in an } \\
\text { open-label randomized prospective } \\
\text { study administering } 3.3 \mathrm{~g} / \mathrm{d} \text { enteral } \\
\text { fish oil in patients with acute } \\
\text { pancreatitis [67] }\end{array}$ & & & \\
\hline Meta-analyses & & & & $\begin{array}{l}\text { Current data are not } \\
\text { sufficient to support the } \\
\text { concept of omega-3 PUFA } \\
\text { supplementation for the } \\
\text { treatment of inflammatory } \\
\text { bowel disease [68] }\end{array}$ \\
\hline
\end{tabular}

NASH: nonalcoholic steatohepatitis.

invasion, and angiogenesis. Actually, it is quite astonishing how many signaling pathways and molecular targets have been so far implicated in the antineoplastic effects of these dietary compounds [8, 15, 154-156]. However, it has been hypothesized that these fatty acids may more directly act through just a few main direct routes and consequently influence the activity/expression/levels of plenty of cellular pathways and molecules more or less specifically altered in the different cancer tissues. Actually, the topic concerning the mechanisms underlying the omega-3 PUFA antineoplastic action is very complex and beyond the focus of this review. Several exhaustive reviews have been previously written by us and others that critically analyzed the possible cell signaling pathways involved in omega-3 antineoplastic action. The readers may refer to them to have a more complete view $[8,15,154-159]$.

Nevertheless, the main direct routes through which omega-3 PUFA are hypothesized to more directly act are worth mentioning here. One of these routes is related to the omega-3 PUFA increased incorporation in cell membranes, as it happens consequently to their increased dietary intake. As a result, physical-chemical alterations of molecular lipid microenvironments (rafts) take place on cell surface [160]. These modifications may in turn lead to changes in the activity/expression of membrane constituents (receptors, channels, enzymes, adapter proteins, etc.) and multiple molecular pathways placed downstream. For instance, it was recently observed [121] that the incorporation of DHA in immortalized colonocytes in vitro altered the lateral organization of the Epidermal Growth Factor Receptor (EGFR), thus leading to increased ligand-induced receptor dimerization and phosphorylation along with its internalization and degradation. These changes, in turn, resulted in the disruption of the EGFR-Ras-ERK1/2 signaling cascade and the inhibition of cell proliferation. Accordingly, in chronically inflamed, carcinogen-injected mice, these authors found that a DHA-enriched diet induced the same effects observed in vitro on the EGFR signaling pathway and also inhibited tumor development. Similarly, we recently found [161] that DHA could dislocate from colon cancer cell surface the antiapoptotic Glucose Related Protein of $78 \mathrm{kDa}$ (GRP78), abnormally expressed on cancer cells plasma membranes [162], where it acts as a signaling receptor promoting proliferation and survival. Through this mechanism, DHA inhibited the ERdj5/PERK/caspase- 4 and caspase-7 pathway placed downwards and induced apoptosis [161].

A second main possible direct route for the omega-3 PUFA action is related to their high peroxidability that makes them optimal substrates for oxidants inside the cells [163]. Through this route, these fatty acids may induce alterations of the cell oxidative status and modulation of oxidative stressdependent molecular pathways related to cell proliferation, apoptosis, or inflammation.

Moreover, a third main direct route for the omega-3 PUFA action is related to their possible metabolic conversion into bioactive molecules with powerful anti-inflammatory and proresolving action (i.e., resolvins, protectins, etc.). Receptors binding specifically to both these bioactive molecules (such as ChemR23, leukotriene B4 receptor 1, LTB4R1, and G protein coupled receptor, GRP32) [164] as well as to omega-3 
PUFA (such as peroxisome proliferator activated receptor $\gamma, \operatorname{PPAR} \gamma$, and G protein coupled receptor, GPR120) have been recently identified $[164,165]$. The signaling starting from these receptors may be translated downwards into the induction of specific cellular molecular pathways.

Finally, a very interesting possibility that may represent the field of future promising investigation in this research area is that omega-3 PUFA, through one or more of these main direct routes, may in turn affect DNA cytosine methylation, the covalent modifications of histones, or the expression of noncoding microRNA (miRNA). These effects may alter the epigenetic control of genes codifying proteins involved in cell proliferation and survival. It has been already hypothesized that alterations of epigenetic control of gene expression could be involved in the beneficial effects that omega-3 PUFA exert in immunological or neurodegenerative diseases [166-168] or in some kinds of cancer [157, 169-171].

5.2. Omega-3 PUFA in Colon Cancer. Dietary omega-3 PUFA have attracted considerable interest for their potential to prevent the development and progression of colorectal cancer (CRC) $[8,158,172]$. An impressive body of evidence has been obtained in preclinical studies using in vivo CRC models, consistently supporting the antineoplastic role of omega-3 PUFA $[8,154,172]$, in spite of the high variability of the models and experimental conditions used $[134,135,154,173$, 174]. Among all these data only very few were in conflict with a protective effect of the omega-3 PUFA [127, 175], but in these cases extremely high doses of LC-omega-3 PUFA were administered (about 3-7g EPA + DHA/kg body weight in mouse or $12 \mathrm{~g} \mathrm{EPA} \mathrm{+} \mathrm{DHA/kg} \mathrm{body} \mathrm{weight} \mathrm{in} \mathrm{rat;} \mathrm{for} \mathrm{the}$ calculation used, see [216]). These high doses may generate vast amounts of oxidized products with high prooxidant and carcinogenic activity [26].

Many in vitro studies $[8,154,172]$ confirmed the antineoplastic activity of omega-3 PUFA and, as discussed in the previous section, allowed identification of possible biological and molecular mechanisms [154]. Remarkably, among the in vitro studies [176-178] are those that recently investigated the possible effects of omega-3 PUFA on colorectal cancer stem cells (CCSC). It is believed that CCSC may drive colon tumorigenesis, being principal targets of tumorigenic genetic alterations, due to their long lifespan and capacity for selfrenewal. Moreover, they have also been related to cancer relapse, acquisition of chemotherapy resistance, and metastasis [179]. CCSC are characterized for lacking specific markers of colonic epithelium differentiation, such as cytokeratin 20 (CK20) or mucin 2 (MUC2), and expressing instead specific clusters of differentiation, such as CD133 or Lgr5 antigens (labeling undifferentiated cells) [180-182]. Moreover, most of cancer stem cells form spheres when cultured in serumfree conditions that are highly tumorigenic if injected in immunodeficient mice $[176,178]$. Yang et al. [176] cultivated cancer stem-like cell spheres derived from SW620 colon cancer cell line and showed that both EPA and DHA (10$70 \mu \mathrm{M}$ ) inhibited their growth by inducing apoptosis and that the effect was markedly increased when they acted simultaneously. Moreover, EPA and DHA enhanced the efficacy of chemotherapeutics agents such as 5-fluorouracil
(5-FU) and mitomycin C. Instead, de Carlo et al. [177] found that whereas $25 \mu \mathrm{M}$ EPA inhibited the growth of the COLO 320 DM colon cancer cell line in vitro, it was unable to inhibit that of its CD133+ subpopulation. However, EPA upregulated CK20 and MUC2 and downregulated CD133 expression, thus indicating that it triggered the transition of CCSC to a more differentiated cancer cell phenotype. The authors hypothesized that the increased degree of CCSC differentiation induced by EPA could be strictly related to the EPA-induced sensitization of CD133+ cells to the anticancer agent 5-FU that they observed. Accordingly, Vasudevan et al. [178] found that EPA alone and especially in combination with 5-FU + oxaliplatin (FuOX) was effective in inhibiting cell growth and sphere formation, as well as in inducing apoptosis of (FuOX-) resistant HT-29 and HCT116 CRC, highly enriched in CCSC.

The confirmation in different experimental settings [176178] that omega-3 PUFA can increase the sensitivity of colon CCSC to conventional antineoplastic drugs is very interesting, since, as reviewed by us and others previously [183-185], the most feasible potential anticancer application for these fatty acids in humans will be their possible use as adjuvantsto help increase nutrition status, as well as affort/modulate anticancer effects-in combination with conventional or single-targeted anticancer therapies.

If we turn to consider the interventional studies conducted on healthy volunteers, CRC patients, or subjects at high risk for CRC, the majority of them have concurred to demonstrate the beneficial antineoplastic effect of omega-3 PUFA (Tables 5(a) and 5(b)). The first studies were performed about twenty years ago by supplementing purified EPA + DHA or fish oil (FO). They demonstrated the efficacy of these FA in inhibiting abnormal CRC cell proliferation [83-85, 87], when given either in higher amounts (daily dose: 8-9 g EPA + DHA) for short (2 weeks) and longer periods (3-6 months) or in lower amounts (daily dose: 2.5-4 g EPA + DHA) after one month [85]. However, when the same treatment was performed in the presence of a basal high-fat diet and a low omega-3/omega-6 PUFA ratio of 0.25 , no effect on rectal mucosa cell proliferation was observed [86], confirming that the efficacy of omega-3 PUFA is dependent on both the total lipid content and the omega-3/omega-6 PUFA ratio of the diet. Also Gee et al. [88] did not find any change in cell proliferation by administering $2.4 \mathrm{~g} /$ day EPA + DHA for 3 months, but in this case there is no available information on basal diet or dietary omega-3/omega-6 PUFA ratio. Instead, Cheng et al. [89], who treated patients at high risk for CRC with lower doses (as FO, about $500 \mathrm{mg}$ EPA + DHA/day), but for a very long period (2 years), observed apoptosis induction in the mucosa adjacent to the resected CRC [89]. More recently, Courtney et al. [90] administered gastroresistant capsules containing EPA-free fatty acid (FFA, $2 \mathrm{~g}$ /day) and confirmed the inhibition of cell proliferation and induction of apoptosis in colonic mucosa of subjects at high risk for CRC cancer. The same treatment was recently shown [91] to reduce the number and size of rectal polyps in familial adenomatous polyposis (FAP) and to inhibit angiogenesis in patients carrying CRC liver metastases [92]. A large multicenter trial (seAFood Polyp Prevention Trial) [153] is now being 


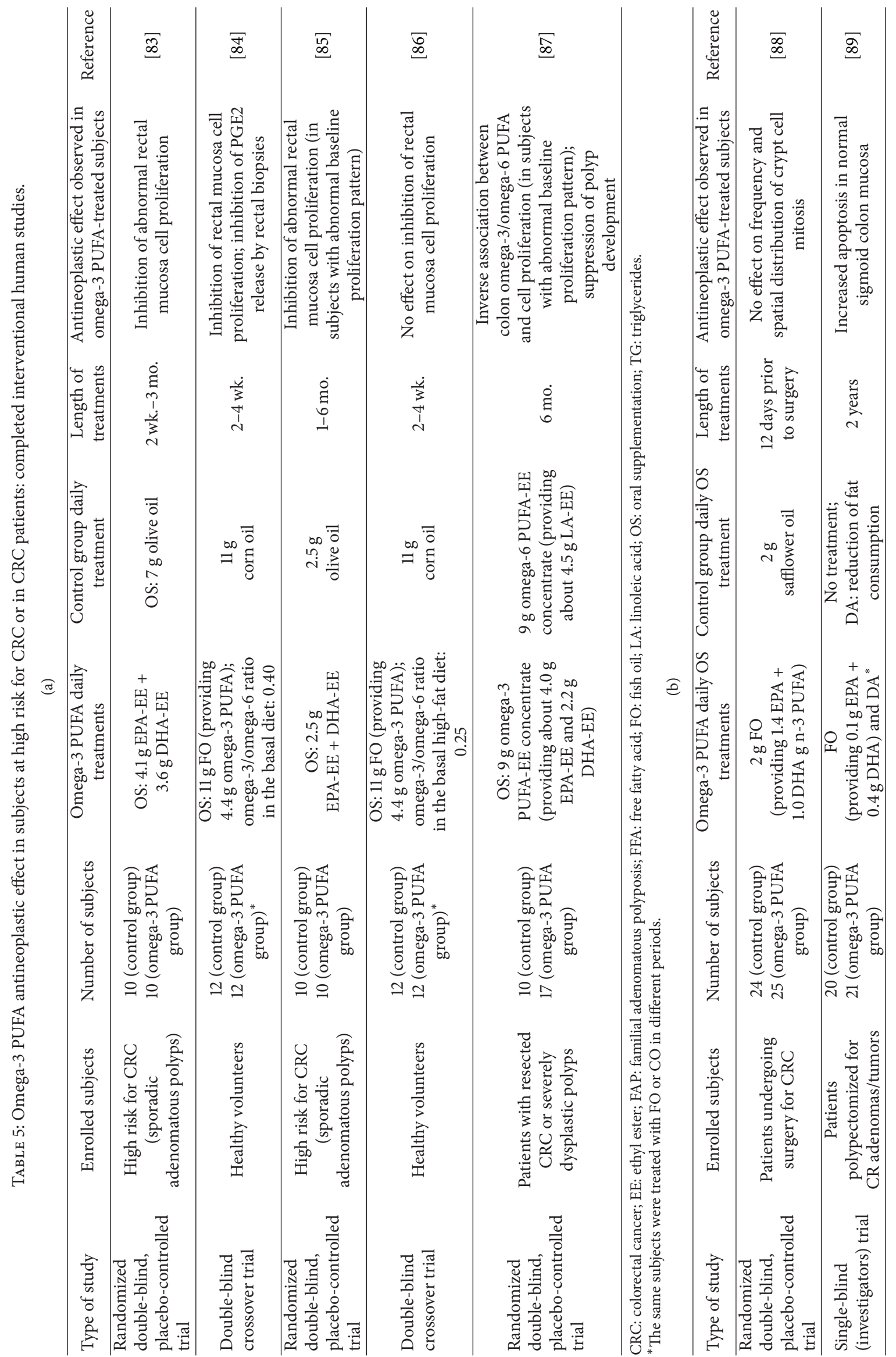




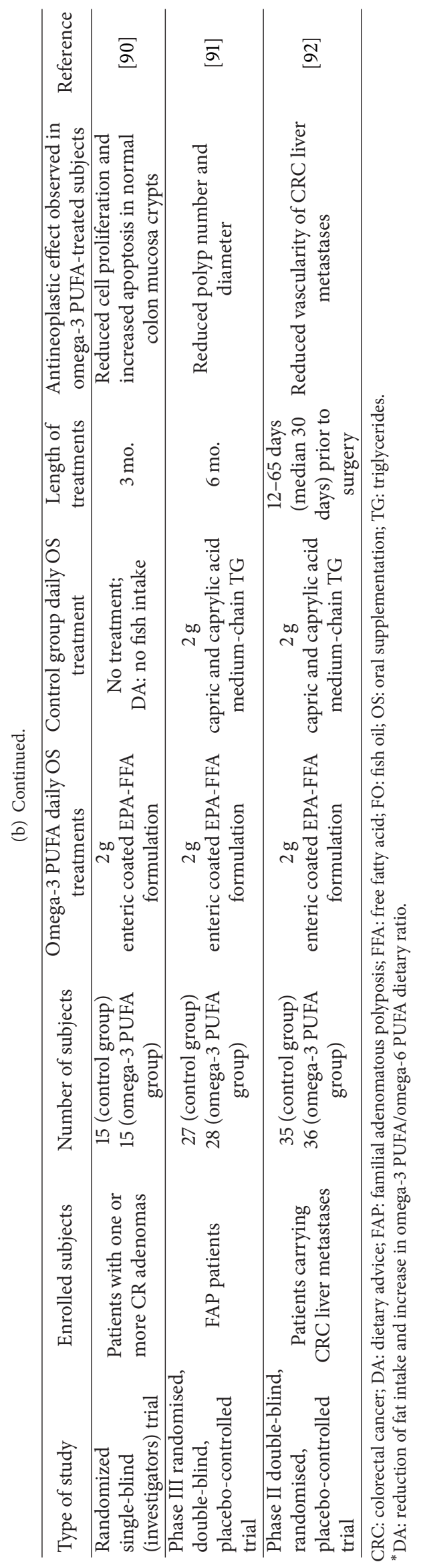


conducted, supplementing the EPA-FFA formulation alone or in combination with aspirin to patients at high risk for developing colorectal adenomas. It would be interesting also to study the effect of DHA in the same formulation, since antineoplastic activities have also been reported for both fatty acids [155]. Moreover, even though EPA can be metabolically converted into DHA and DHA retroconverted into EPA, the in vivo efficiency of these two metabolic reactions may be substantially different [186].

The outcomes of the recent large multicentric interventional FISHGASTRO study [93, 94] showed that an extra $300 \mathrm{~g} /$ week fish serving for 6 months lowered significantly the serum C-Reactive Protein (CRP) concentration in all the subjects, but it did not alter the levels of several inflammation markers in fecal water and colonic biopsies or change the apoptotic rates in colonic mucosa. However, the mitotic rate decreased in the fish groups, even though the significance was not attained [93]. Still, it is possible to hypothesize that the small extra supplementation on top of an already large amount of fish consumed at baseline (corresponding to about 0.09 or $1.4 \mathrm{~g} \mathrm{EPA} \mathrm{+} \mathrm{DHA/day)} \mathrm{was} \mathrm{not} \mathrm{sufficient}$ to induce significant alterations in mucosal cell growth and survival. The reduction in serum CRP levels was confirmed in a recent trial conducted by Mocellin et al. [95] in CRC patients treated daily with FO containing $0.6 \mathrm{~g} \mathrm{EPA}+\mathrm{DHA}$, supporting a general anti-inflammatory effect of omega-3 PUFA supplementation.

After more than twenty years of intense research, several meta-analyses and systematic reviews of the literature have been recently published on this topic. If we take into account only the most recent ones [100-102], their conclusions appear not to be in agreement. Gerber [102] updated the observations of the previous meta-analysis conducted by the FAO/OMS experts [101] to April 2011 and prudently concluded that overall, owing primarily to insufficient homogeneity of the observations, the studies analyzed provided only limited evidence suggesting a role for omega-3 PUFA in CRC prevention [102]. Wu et al. [100] considered in their meta-analysis 22 prospective cohort and 19 case-control studies performed until 2011. They more decidedly concluded that fish consumption was inversely associated with CRC. In particular, they found a significant inverse association between fish intake and rectal cancer and only a modest trend between fish consumption and colon cancer.

Since then, several other case-control and cohort studies were published. In their case-control studies, Murff et al. [96] and Habermann et al. [99] demonstrated an inverse association between an increased omega-3 PUFA dietary intake and the risk of developing colorectal neoplasms (adenocarcinomas or adenomas) [96, 99]. However, benefits were limited only to some of the subpopulations investigated. In particular, Murff et al. [96] showed that an increased omega-3 PUFA intake was associated with reduced risk of colorectal adenomas in women only, whereas Habermann et al. [99] found that an inverse association between low DHA intake and increase in CRC risk was confined to patients showing specific genetic variants that resulted in higher levels of proinflammatory mediators.
Recent cohort studies found associations only in subcohorts. Kantor et al. [97] found an inverse association between FO use and cancer risk, but only at the level of the colon (not rectum) and only in men (not in women). Moreover, the same authors [97] found that fish consumption or EPA/DHA intake was not associated with CRC risk overall but that associations were significantly modified by genetic risk, with inverse associations among low-moderate genetic risk groups and positive associations among high risk groups. The cohort study of Song et al. [98] found no association between fish/omega-3 PUFA intake and overall CRC incidence. In contrast with the Kantor et al. study [97], Song et al. [98] found an inverse association between a high LC-omega-3 PUFA consumption and rectal cancer (but not colon cancer) and even a positive association between LC-omega-3 PUFA increased intake and distal colon cancer.

The controversial findings in epidemiological studies now need clarification in the setting of large randomized clinical intervention trials, such as the one currently ongoing [153]. The current state of evidence for the effects of omega-3 PUFA in human studies regarding colorectal cancer and the contrasting outcomes have been summarized in Table 6. Possible reasons for the controversies in the field are reported in Section 6.

5.3. Omega-3 PUFA in Prostate Cancer. Recently, Brasky et al. [25] suggested a potential prostate cancer promoting effect of omega-3 PUFA, leading to a new round of discussions on the effects of omega-3 PUFA in prostate cancer [26, 187-195]. Even though many researchers hold the view that omega-3 PUFA intake is beneficial in this cancer type, the association between omega-3 PUFA and prostate cancer risk is not without controversy. On one hand, a case-control study with 3141 participants in Canada provided an inverse association between fish consumption and prostate cancer incidence and subsequently suggested that fish consumption may reduce the risk of developing prostate cancer [103]. Accordingly, a study focusing on aggressive prostate cancer also found that a high intake of omega-3 PUFA was strongly associated with a decreased risk of aggressive prostate cancer, and the odd ratio (OR) for prostate cancer comparing the highest with the lowest quartile of omega-3 intake was 0.37 (0.25-0.54) [106]. Moreover, Szymanski's meta-analysis showed an association between fish consumption and a significant $63 \%$ reduction in prostate cancer-specific mortality [116]. Chavarro et al. found that, compared to prostate cancer patients who consume fish less than once a week, patients who consume at least 5 times more fish per week had a $48 \%$ lower risk of prostate cancer death [108]. Torfadottir et al.s study [110] on Icelanders found a negative correlation between risk of advanced prostate cancer and FO consumption in later life. Due to daily intake of omega-6 PUFA from the diet, the role of the omega-6/omega3 PUFA ratio has also been considered. Williams et al. [104] found that the ratio of dietary omega-6/omega-3 PUFA was significantly associated with increased risk of high-grade, but not low-grade prostate cancer. Moreover, it has also been found $[196,197]$ that omega-3 PUFA or a low ratio of omega- 6 to omega-3 PUFA could decrease the proliferation of prostate cancer cells in cell culture experiments. Based upon these 
TABLE 6: Current state of evidence for the effects of omega-3 PUFA in published human studies regarding colorectal cancer.

\begin{tabular}{|c|c|c|c|c|}
\hline Type of study & Beneficial effect & $\begin{array}{l}\text { Beneficial effect limited to } \\
\text { subpopulation }\end{array}$ & $\begin{array}{l}\text { Detrimental effect } \\
\text { limited to } \\
\text { subpopulations }\end{array}$ & No effect \\
\hline \multirow{5}{*}{ Clinical trials } & $\begin{array}{l}\text { Antiproliferative effect } \\
{[83-85,87,90]}\end{array}$ & & & $\begin{array}{l}\text { No antiproliferative } \\
\text { effect }[86,88,93,94]\end{array}$ \\
\hline & Proapoptotic effect $[89,90]$ & & & $\begin{array}{l}\text { No proapoptotic } \\
\text { effect }[93,94]\end{array}$ \\
\hline & $\begin{array}{l}\text { Reduced polyp number and } \\
\text { size in FAP [91] }\end{array}$ & & & $\begin{array}{l}\text { No anti-inflammatory } \\
\text { effect in colony } \\
\text { biopsies }[93,94]\end{array}$ \\
\hline & Reduced angiogenesis [92] & & & \\
\hline & $\begin{array}{l}\text { Reduced CRP levels in } \\
\text { serum }[93-95]\end{array}$ & & & \\
\hline \multirow{5}{*}{$\begin{array}{l}\text { Observational } \\
\text { studies }\end{array}$} & & $\begin{array}{l}\text { Inverse association between } \\
\text { increased dietary intake and risk } \\
\text { of CR adenomas (only in } \\
\text { women) [96] }\end{array}$ & $\begin{array}{l}\text { Positive associations } \\
\text { between FO use and } \\
\text { CRC in high risk groups } \\
{[97]}\end{array}$ & \\
\hline & & $\begin{array}{l}\text { Inverse association between FO } \\
\text { use and cancer risk (in men, not } \\
\text { in women; in colon, not in } \\
\text { rectum) [97] }\end{array}$ & $\begin{array}{l}\text { Positive association } \\
\text { between increased } \\
\text { intake and distal CC [98] }\end{array}$ & \\
\hline & & $\begin{array}{l}\text { Inverse associations between FO } \\
\text { use and CRC in low-moderate } \\
\text { genetic risk groups, and positive } \\
\text { associations among high risk } \\
\text { groups [97] }\end{array}$ & & \\
\hline & & $\begin{array}{l}\text { Inverse association between } \\
\text { increased intake and RC (but not } \\
\text { CC) }[98]\end{array}$ & & \\
\hline & & $\begin{array}{l}\text { Inverse association between } \\
\text { increased dietary intake and risk } \\
\text { of CRC (only in specific genetic } \\
\text { variants) [99] }\end{array}$ & & \\
\hline Meta-analyses & $\begin{array}{l}\text { Significant inverse } \\
\text { association between fish } \\
\text { consumption and RC [100] }\end{array}$ & & & $\begin{array}{l}\text { Limited evidence of a } \\
\text { role in CRC } \\
\text { prevention }[101,102]\end{array}$ \\
\hline
\end{tabular}

CC: colon cancer; CRC: colorectal cancer; CRP: C-Reactive Protein; FAP: familial adenomatous polyposis; FO: fish oil; RC: rectal cancer.

association observations and considerable amounts of in vivo and in vitro experimental evidence [198, 199], several mechanistic hypotheses have been proposed to explain these phenomena. In particular, as already described in detail in Section 5.1, PUFA can be converted into many bioactive metabolites, which play various roles in modulating cell proliferation, apoptosis, and immune regulation. Many of the metabolites derived from omega- 6 arachidonic acid (AA), including prostaglandin E2 and leukotriene B4, were shown to stimulate prostate cancer $[200,201]$.

On the other hand, several other studies did not provide evidence of a protective role of omega-3 against prostate cancer. Kristal et al's study [107] suggested that there was no association between omega-3 PUFA intake and prostate cancer risk. Brouwer's meta-analysis showed that the status of EPA or DHA did not associate with prostate cancer risk [117]. Park et al. [109] found no significant association between erythrocyte membrane omega-3 PUFA (EPA, DPA, or DHA) and total or advanced/high-grade prostate cancer risk. In
Mannisto's study among male smokers [111], no association between serum EPA or DHA and prostate cancer risk was found. Harvei et al. [115] could not identify a clear association between prostate cancer risk and total serum phospholipid (PL) omega-3 PUFA either. A study based on the 20032010 National Health and Nutrition Examination Survey (NHANES) [114] found no association between omega-3 PUFA intake and prostate-specific antigen (PSA) level. Chua et al. [112] found that a high blood docosapentaenoic acid (DPA) level was negatively associated with total risk of prostate cancer. In contrast, a significant positive association between EPA or DHA and high-grade prostate cancer was shown [112]. Similarly, Sorongon-Legaspi et al's study [113] showed that DPA blood level was negatively linked with total prostate cancer risk and high EPA and DHA blood levels were associated with high-grade prostate cancer risk. Crowe et al. [105] described a positive association between EPA and risk of only high-grade prostate cancer, while DHA could not be linked to risk of any stages of prostate cancer. 
TABLE 7: Current state of evidence for the effects of omega-3 PUFA in published human studies regarding prostate cancer.

\begin{tabular}{|c|c|c|c|c|}
\hline Type of study & Beneficial effect & $\begin{array}{l}\text { Beneficial effect } \\
\text { limited to } \\
\text { subpopulations }\end{array}$ & $\begin{array}{l}\text { Detrimental effect } \\
\text { limited to } \\
\text { subpopulations }\end{array}$ & No or detrimental effects \\
\hline \multirow{8}{*}{$\begin{array}{l}\text { Observational } \\
\text { studies }\end{array}$} & $\begin{array}{l}\text { Inverse association between } \\
\text { fish consumption and } \\
\text { cancer incidence [103] }\end{array}$ & $\begin{array}{l}\text { Dietary } \\
\text { omega-3/omega-6 } \\
\text { PUFA ratio inversely } \\
\text { associated with risk of } \\
\text { high-grade cancer } \\
{[104]}\end{array}$ & $\begin{array}{l}\text { Positive association } \\
\text { between EPA and risk of } \\
\text { only high-grade cancer } \\
{[105]}\end{array}$ & $\begin{array}{l}\text { Dietary omega-3/omega- } 6 \\
\text { PUFA ratio not associated } \\
\text { with risk of low-grade } \\
\text { cancer }[104]\end{array}$ \\
\hline & $\begin{array}{l}\text { Inverse association between } \\
\text { high intake and risk of } \\
\text { aggressive cancer [106] }\end{array}$ & & $\begin{array}{l}\text { Positive association } \\
\text { between high serum PL } \\
\text { LC-omega-3 PUFA and } \\
\text { cancer risk [25] }\end{array}$ & $\begin{array}{l}\text { No association between fish } \\
\text { or FO intake and cancer } \\
\text { risk [107] }\end{array}$ \\
\hline & $\begin{array}{l}\text { Inverse association between } \\
\text { higher fish intake and risk } \\
\text { of cancer death [108] }\end{array}$ & & & $\begin{array}{l}\text { No association between } \\
\text { erythrocyte membrane } \\
\text { EPA, DPA, or DHA and } \\
\text { total or } \\
\text { advanced/high-grade } \\
\text { cancer risk [109] }\end{array}$ \\
\hline & $\begin{array}{l}\text { Inverse association between } \\
\text { FO intake and risk of } \\
\text { advanced cancer later life } \\
{[110]}\end{array}$ & & & $\begin{array}{l}\text { No association between } \\
\text { serum EPA or DHA and } \\
\text { cancer risk in male smokers } \\
\text { [111] }\end{array}$ \\
\hline & $\begin{array}{l}\text { Inverse association between } \\
\text { DPA level and total risk of } \\
\text { cancer }[112,113]\end{array}$ & & & $\begin{array}{l}\text { No association between } \\
\text { omega-3 PUFA intake and } \\
\text { PSA level [114] }\end{array}$ \\
\hline & & & & $\begin{array}{l}\text { Positive association } \\
\text { between EPA or DHA and } \\
\text { high-grade cancer }[112,113]\end{array}$ \\
\hline & & & & $\begin{array}{l}\text { No association between } \\
\text { DHA level and risk of } \\
\text { cancer at any stages [105] }\end{array}$ \\
\hline & & & & $\begin{array}{l}\text { No association between } \\
\text { total serum PL omega-3 } \\
\text { PUFA and cancer risk [115] }\end{array}$ \\
\hline Meta-analyses & $\begin{array}{l}\text { Inverse association between } \\
\text { fish intake and prostate } \\
\text { cancer-specific mortality } \\
{[116]}\end{array}$ & & & $\begin{array}{l}\text { No association between FO } \\
\text { intake or EPA/DHA blood } \\
\text { level and cancer risk [117] }\end{array}$ \\
\hline
\end{tabular}

FO: fish oil; PL: phospholipids; PSA: prostate-specific antigen.

As mentioned above, in their recently published casecontrol substudy from the SELECT study population Brasky et al. [25] reported a positive association between high plasma phospholipid omega-3 PUFA content at baseline and prostate cancer. However, we should underline that the SELECT trial was not addressing omega-3 PUFA supplementation for the prevention of prostate cancer. The authors used data from two case-control studies [25, 202], nested within intervention trials which were unrelated to eating fish or taking omega3 supplements. In these studies, the dietary intake of fish or omega-3 had not been analyzed, neither advice was given to eat fish or take fish oil supplement [194]. Moreover, omega-3 PUFA were measured only once at baseline and only in plasma phospholipids [27] and not in red blood cell membranes. In fact, it has been suggested that evaluating the "omega-3 index," that is, the incorporation of omega-3 PUFA in erythrocytes, may better reflect the omega-3 PUFA status of the subjects $[77,78]$.

The current state of evidence for the effects of omega-3 PUFA in human studies regarding prostate cancer and the contrasting outcomes have been summarized in Table 7, and additional possible reasons for the controversies in the field are reported in Section 6.

Overall, we can conclude that the literature on the role of omega-3 PUFA in prostate cancer is remarkably consistent among cell culture and animal studies, and controversies came mostly from association studies in human populations. However, the preventive effect of omega-3 PUFA on prostate cancer is still uncertain, and the controversy will probably remain until the mechanisms are clarified. However, while current human data are certainly not sufficient to recommend omega-3 PUFA to prevent prostate cancer, they are also far 
from being sufficient to support a prostate cancer promoting effect of these FA $[188,190,191,193,203,204]$.

\section{Possible Reasons for Controversies}

Several reasons may be responsible for the discrepancies registered among the outcomes of human studies. First of all, it should be considered that even though omega-3 PUFA can be regarded as medication and high-dose preparations are approved as prescription drugs in many parts of the world, omega-3 PUFA are essential part of our diet. Their intake can vary widely from population to population and even within the same person, depending on actual dietary habits or shortterm dietary changes (eating seafood during vacations on the coast). Often, the epidemiological observational studies, particularly the early studies, refer to Food Frequency Questionnaire and Diet Records to establish fish consumption. However, this methodology is prone to measurement errors [205], and a low correlation coefficient (0.11-0.18) has been shown to exist between fish intake frequency and direct measurements of FA in patient samples [205, 206], even after adjusting for confounding factors, such as age [207, 208]. A number of other variables may contribute to this scarce correlation, such as the individual capacity to adsorb and make the PUFA bioavailable at the serum level, the fat content of the diet, or the omega-3/omega-6 PUFA dietary ratio. Moreover, different methods are used to calculate dietary fats or specific FA in the diets [209]. Often the questionnaires refer only to fish servings per week, without considering the serving size or the kind of fish consumed (lean fish or fatty fish) [207]. It is known that there exists an extreme variability in fish intake among populations, and if we consider the amount of fish ingested by the "low fish consumers" among the populations at high fish intake, it may correspond to or be even higher than the amount consumed by the "high fish consumers" in the populations at low fish intake. As a matter of fact, positive association between dietary intake of omega3 PUFA and health effects has been registered mainly among population eating fish at high levels [15]. Some intrinsic weaknesses of questionnaire studies could thus be addressed by actually measuring omega-3 PUFA in the participants. Some more recent studies have directly evaluated the levels of omega-3 PUFA in serum, in different plasmatic lipid classes, or in erythrocytes [210-212]. Whereas it has been argued that measuring the omega-3 PUFA level only in one class of plasma lipids may be misleading [27], it has been suggested that erythrocyte EPA and DHA content (named "omega-3 index") may better reflect the omega-3 PUFA status of the subjects $[77,78]$. This is because the plasma-based measurements merely represent the short-term availability of omega-3 PUFA, being susceptible to artificial elevation following an acute omega-3 PUFA load [213]. Indeed, it has been recently reported that an acute single dose $(3.4-4 \mathrm{~g} / \mathrm{d})$ of omega-3 PUFA, in the form of either prescription medication or dietary supplements, peaked plasma EPA + DHA levels as early as $5 \mathrm{~h}$ after administration, whereas the EPA plus DHA concentrations in erythrocyte membranes were only increased by approximately 10 orders of magnitude less than the concurrent plasma (3\% versus 30\%) from baseline at
$24 \mathrm{~h}[214,215]$. Therefore, even if a single evaluation may be confounding, since serum FA are powerfully affected by feeding/fasting cycles and by the lipid content of the last meal consumed [27], one possibility of overcoming the discrepancies in omega-3 PUFA research is to call for actual correlation of questionnaire-based calculations of omega3 PUFA intake with at least one actual measurement per participant in order to obtain some biochemical information regarding actual omega-3 PUFA levels.

Moreover, we ask if intervention studies administering defined amounts of omega-3 PUFA may solve this problem. At least these studies exactly define the amount of omega-3 PUFA administered. A rather big problem with these studies is the big range of doses of omega-3 PUFA administered on one hand and the variability of baseline diets on the other hand. In order to understand discrepancies and problems of omega-3 PUFA efficacy in intervention trials, we will have to regard the omega-3 PUFA as parts of diet and component of normal human body homeostasis. This is a concept obviously radically different from synthetic drug studies and something that has always to be taken into account when assessing intervention studies. In such studies, the animals/subjects have been treated with specific and controlled amounts of omega-3 PUFA. But most of these studies neither established baseline omega-3 PUFA body content in the participants nor monitored omega-3 PUFA during the study, making proper interpretation of the obtained results difficult. A recent study properly addressing these issues was the Welcome Trial in $\mathrm{NASH}$ patients, in which interpretation of the data focused on the correlation of measured DHA enrichment with liver fat content, as well as on pure ITT analysis of the treatment group. It demonstrated a statistically significant linear correlation between decreased liver fat content and increased DHA enrichment, but no significant effect in the ITT treatment group analysis [64]. Therefore, as in observational studies, intervention trials should perform biochemical analyses of omega-3 PUFA content to (1) define baseline levels in the different groups and (2) determine actual changes in the different groups due to the treatment as compared to the placebo group, where some of the participants might actually contaminate the results by starting to consume a high fish diet during the trial period.

Omega-3 PUFA dose is an issue as well. The omega-3 PUFA dose was very high in earlier animal studies, ranging from 2.0 to 8.0 (EPA + DHA g/kg body weight/day in mice) in most cancer studies [216]. But even the lower doses used for animals, after the interspecies conversion [217], appear rather high for humans (about 10-20 g/day in a person weighing $70 \mathrm{~kg}$ ). However, it is remarkable that, at least in the few human interventional trials completed in the cancer field, the preventive effects were noticed with doses of only $2.0 \mathrm{~g} /$ day (corresponding to about $0.03 \mathrm{~g} / \mathrm{kg}$ body weight in a person weighing $70 \mathrm{~kg})[85,91,218,219]$. The positive anticancer effects were accompanied (if evaluated) by a comparable increase (ranging from 2-3- to 5-fold) in omega-3 PUFA incorporation in plasma or tissue lipids, in both animals and humans [216].

The source of the omega-3 PUFA ingested may also be important. Interventional studies often use highly purified 
omega-3 PUFA. They may help to obtain more clear results than the use of fish/FO, since fish also represents a good source of selenium, various vitamins, taurine, and other compounds that have been shown to possess potential protective effects [220-222]. Moreover, high levels of contaminant and dangerous agents may accumulate in fish tissues and fat. Some of these agents (such as organochlorine pesticides or $\mathrm{Hg}$ ) are environment-derived and may be present in the tissues of both farmed and wild fish (especially predator fish). Moreover, other cytotoxic and carcinogenic products of omega-3 PUFA may be formed in fish after cooking them at extremely high temperature (by broiling/frying fish) or preserving them by smoking procedures [26]. The omega3 PUFA oxidative products may be formed in omega-3 fortified food and in omega-3 supplements that do not contain adequate levels of antioxidants and are stored at room temperature for a long time [26]. Furthermore, the general composition of the diet has to be taken into account, since the effect of increased omega-3 PUFA uptake might be different in the context of a high-carbohydrate diet as compared to a high-fat diet. This might change absorption and processing of the omega-3 PUFA and thus affect actual concentrations in the body. In addition, the highly critical factor omega- 6 PUFA and the actual omega-6/omega-3 PUFA dietary ratio may deeply alter the effects of omega-3 PUFA supplementation.

Considerable attention has been drawn recently to the possibility that interactions may exist between the subject genetic background and the effects of nutritional interventions [223, 224]. Different observational studies have already demonstrated that the inverse association between omega3 PUFA intake or plasma/tissue enrichment and the risk of several diseases may be limited only to subpopulations possessing specific genetic features/signatures [99, 106, 225230]. Genetic differences or gender-specific effects [97] might be due to differences in the expression of effector proteins for the omega-3 PUFA and their lipid mediator products, but also due to differences in enzymes of lipid metabolism that might lead to differences in the processing of the omega-3 PUFA in the body. Both issues, assessing the source of omega-3 PUFA and dietary composition as well as genetic background affecting handling of the omega-3 PUFA, also call for more measurements to better understand controversial results.

\section{Conclusions}

Our review of the omega-3 PUFA research literature prompts us to conclude that the animal and in vitro data have been remarkably consistent in showing health benefits, particularly through mechanisms dampening inflammation and proliferation in different tissues. These results have established potential protective effects of omega-3 PUFA in diseases ranging from cardiac arrhythmia and inflammatory conditions (atherosclerosis to airway inflammation, colitis, pancreatitis, steatohepatitis, arthritis, etc.) to tumorigenesis (particularly colon and liver tumors, but also breast and prostate cancer). On the other hand, the outcomes of human studies have been so far quite controversial. Therefore, in order to shed more light on this point and better understand if the divergences were ascribable to possible methodological weaknesses in human studies or, alternatively, to different responses of human cells/tissues to the incorporation of omega-3 as compared to those of laboratory animal species, it is suggested that all future studies in this field should perform blood FA measurements in trial participants. These evaluations should be preferably performed in blood cells, and, whenever possible, at baseline as well as at different time-points during the study. This procedure would also be extremely helpful to (1) monitor the effect of the huge omega3 PUFA supplement industry in the western world on omega3 PUFA content in humans, (2) understand the effect of other FA in the context of omega-3 PUFA interventions, and (3) recognize variations in individual responses to omega-3 PUFA supplementation.

\section{Conflict of Interests}

The authors declare that there is no conflict of interests regarding the publication of this paper.

\section{Authors' Contribution}

Karsten H. Weylandt and Simona Serini contributed equally to this work.

\section{Acknowledgments}

This work was supported in part by the following grants: Linea D.3.2 2013 and Linea D1 2012 Università Cattolica del Sacro Cuore, Rome, Italy, to Gabriella Calviello; National Research Foundation of Korea (NRF) grant funded by the Korea government (MSIP) (no. 2007-0054932) to Kyu Lim.

\section{References}

[1] W. S. Harris, T. D. Dayspring, and T. J. Moran, "Omega-3 fatty acids and cardiovascular disease: new developments and applications," Postgraduate Medicine, vol. 125, no. 6, pp. 100-113, 2013.

[2] D. Kromhout and J. de Goede, "Update on cardiometabolic health effects of $\omega$-3 fatty acids," Current Opinion in Lipidology, vol. 25, no. 1, pp. 85-90, 2014.

[3] G. Calviello, S. Serini, and E. Piccioni, "Alzheimer's disease and n-3 polyunsaturated fatty acids: beneficial effects and possible molecular pathways involved," Current Signal Transduction Therapy, vol. 3, no. 3, pp. 152-157, 2008.

[4] C. I. F. Janssen and A. J. Kiliaan, "Long-chain polyunsaturated fatty acids (LCPUFA) from genesis to senescence: the influence of LCPUFA on neural development, aging, and neurodegeneration," Progress in Lipid Research, vol. 53, no. 1, pp. 1-17, 2014.

[5] G. Young and J. Conquer, "Omega-3 fatty acids and neuropsychiatric disorders," Reproduction Nutrition Development, vol. 45, no. 1, pp. 1-28, 2005.

[6] R. M. Ortega, E. Rodríguez-Rodríguez, and A. M. LópezSobaler, "Effects of omega 3 fatty acids supplementation in behavior and non-neurodegenerative neuropsychiatric disorders," British Journal of Nutrition, vol. 107, supplement 2, pp. S261-S270, 2012. 
[7] P. C. Calder, "Marine omega-3 fatty acids and inflammatory processes: effects, mechanisms and clinical relevance," Biochimica et Biophysica Acta-Molecular and Cell Biology of Lipids, vol. 1851, no. 4, pp. 469-484, 2015.

[8] G. Calviello, S. Serini, and E. Piccioni, "n-3 polyunsaturated fatty acids and the prevention of colorectal cancer: molecular mechanisms involved," Current Medicinal Chemistry, vol. 14, no. 29, pp. 3059-3069, 2007.

[9] P. Bougnoux, N. Hajjaji, K. Maheo, C. Couet, and S. Chevalier, "Fatty acids and breast cancer: sensitization to treatments and prevention of metastatic re-growth," Progress in Lipid Research, vol. 49, no. 1, pp. 76-86, 2010.

[10] Z. Gu, J. Suburu, H. Chen, and Y. Q. Chen, "Mechanisms of omega-3 polyunsaturated fatty acids in prostate cancer prevention," BioMed Research International, vol. 2013, Article ID 824563, 10 pages, 2013.

[11] E. K. J. Pauwels and M. Kostkiewicz, "Fatty acid facts, part III: cardiovascular disease, or, a fish diet is not fishy," Drug News and Perspectives, vol. 21, no. 10, pp. 552-561, 2008.

[12] G. P. Eckert, U. Lipka, and W. E. Muller, "Omega-3 fatty acids in neurodegenerative diseases: focus on mitochondria," Prostaglandins Leukotrienes and Essential Fatty Acids, vol. 88, no. 1, pp. 105-114, 2013.

[13] J. X. Kang and K. H. Weylandt, "Modulation of inflammatory cytokines by omega-3 fatty acids," Sub-Cellular Biochemistry, vol. 49, pp. 133-143, 2008.

[14] T. A. Babcock, T. Dekoj, and N. J. Espat, "Experimental studies defining omega-3 fatty acid antiinflammatory mechanisms and abrogation of tumor-related syndromes," Nutrition in Clinical Practice, vol. 20, no. 1, pp. 62-74, 2005.

[15] G. Calviello, S. Serini, and P. Palozza, "n-3 Polyunsaturated fatty acids as signal transduction modulators and therapeutical agents in cancer," Current Signal Transduction Therapy, vol. 1, no. 3, pp. 255-271, 2006.

[16] C. Boudrault, R. P. Bazinet, and D. W. L. Ma, "Experimental models and mechanisms underlying the protective effects of $n$ 3 polyunsaturated fatty acids in Alzheimer's disease," Journal of Nutritional Biochemistry, vol. 20, no. 1, pp. 1-10, 2009.

[17] R. Liperoti, F. Landi, O. Fusco, R. Bernabei, and G. Onder, "Omega-3 polyunsaturated fatty acids and depression: a review of the evidence," Current Pharmaceutical Design, vol. 15, no. 36, pp. 4165-4172, 2009.

[18] GISSI-Prevenzione Investigators (Gruppo Italiano per lo Studio della Sopravvivenza nell'Infarto miocardico), "Dietary supplementation with n-3 polyunsaturated fatty acids and vitamin $\mathrm{E}$ after myocardial infarction: results of the GISSI-Prevenzione trial. Gruppo Italiano per lo Studio della Sopravvivenza nell'Infarto miocardico," The Lancet, vol. 354, no. 9177, pp. 447455, 1999.

[19] P. Vitello, Alexander Leaf Dies at 92; Linked Diet and Health, New York Times, 2013.

[20] G. De Maria, "Omega-3. An overview. Focus on omega-3," Agro Food Industry Hi-Tech, vol. 19, supplement, pp. 4-9, 2008.

[21] D. Kromhout, E. J. Giltay, and J. M. Geleijnse, "n-3 fatty acids and cardiovascular events after myocardial infarction," The New England Journal of Medicine, vol. 363, no. 21, pp. 2015-2026, 2010.

[22] S. M. Kwak, S.-K. Myung, Y. J. Lee, and H. G. Seo, "Efficacy of omega-3 fatty acid supplements (eicosapentaenoic acid and docosahexaenoic acid) in the secondary prevention of cardiovascular disease: a meta-analysis of randomized, double-blind, placebo-controlled trials," Archives of Internal Medicine, vol. 172, no. 9, pp. 686-694, 2012.

[23] J. Bosch, H. C. Gerstein, G. R. Dagenais et al., "n-3 fatty acids and cardiovascular outcomes in patients with dysglycemia," The New England Journal of Medicine, vol. 367, no. 4, pp. 309-318, 2012.

[24] J. G. Fodor, E. Helis, N. Yazdekhasti, and B. Vohnout, “'Fishing” for the origins of the 'Eskimos and heart disease' story: facts or wishful thinking?" Canadian Journal of Cardiology, vol. 30, no. 8, pp. 864-868, 2014.

[25] T. M. Brasky, A. K. Darke, X. Song et al., "Plasma phospholipid fatty acids and prostate cancer risk in the SELECT trial," Journal of the National Cancer Institute, vol. 105, no. 15, pp. 1132-1141, 2013.

[26] S. Serini, E. Fasano, E. Piccioni, A. R. M. Cittadini, and G. Calviello, "Dietary n-3 polyunsaturated fatty acids and the paradox of their health benefits and potential harmful effects," Chemical Research in Toxicology, vol. 24, no. 12, pp. 2093-2105, 2011.

[27] J. Suburu, K. Lim, G. Calviello, and Y. Q. Chen, "RE: Serum phospholipid fatty acids and prostate cancer risk in the SELECT trial," Journal of the National Cancer Institute, vol. 106, no. 4, Article ID dju023, 2014.

[28] R. T. Holman, S. B. Johnson, and T. F. Hatch, "A case of human linolenic acid deficiency involving neurological abnormalities," The American Journal of Clinical Nutrition, vol. 35, no. 3, pp. 617623, 1982.

[29] L. M. Arterburn, E. B. Hall, and H. Oken, "Distribution, interconversion, and dose response of n-3 fatty acids in humans," American Journal of Clinical Nutrition, vol. 83, no. 6, pp. 1467S1476S, 2006.

[30] A. H. Stark, M. A. Crawford, and R. Reifen, "Update on alphalinolenic acid," Nutrition Reviews, vol. 66, no. 6, pp. 326-332, 2008.

[31] K. Jing, T. Wu, and K. Lim, "Omega-3 polyunsaturated fatty acids and cancer," Anti-Cancer Agents in Medicinal Chemistry, vol. 13, no. 8, pp. 1162-1177, 2013.

[32] G. C. Burdge, "Metabolism of $\alpha$-linolenic acid in humans," Prostaglandins Leukotrienes and Essential Fatty Acids, vol. 75, no. 3, pp. 161-168, 2006.

[33] R. T. Holman, "The slow discovery of the importance of $\omega 3$ essential fatty acids in human health," The Journal of Nutrition, vol. 128, no. 2, supplement, pp. 427S-433S, 1998.

[34] S. A. Scholtz, J. Colombo, and S. E. Carlson, "Clinical overview of effects of dietary long-chain polyunsaturated fatty acids during the perinatal period," Nestle Nutrition Institute Workshop Series, vol. 77, pp. 145-154, 2013.

[35] E. N. Smit, F. A. J. Muskiet, and E. R. Boersma, “The possible role of essential fatty acids in the pathophysiology of malnutrition: a review," Prostaglandins Leukotrienes and Essential Fatty Acids, vol. 71, no. 4, pp. 241-250, 2004.

[36] D. F. Horrobin, "Essential fatty acid metabolism and its modification in atopic eczema," The American Journal of Clinical Nutrition, vol. 71, supplement 1, pp. 367S-372S, 2000.

[37] A. P. Simopoulos, "Human requirement for N-3 polyunsaturated fatty acids," Poultry Science, vol. 79, no. 7, pp. 961-970, 2000.

[38] FAO-WHO, Fats and Fatty Acids in Human Nutrition: Report of an Expert Consultation, FAO Food and Nutrition Paper \# 91, FAO, WHO, Geneva, Switzerland, 2010. 
[39] International Society for the Study of Fatty Acids and Lipids (ISSFAL), Report of the Sub-Committee on: Recommendations for Intake of Polyunsaturated Fatty Acids in Healthy Adults, International Society for the Study of Fatty Acids and Lipids (ISSFAL), 2004.

[40] A. F. Luzzi and W. P. T. James, "European diet and public health: the continuing challenge," Public Health Nutrition, vol. 4, no. 2A, pp. 275-292, 2001.

[41] B. Koletzko, E. Lien, C. Agostoni et al., "The roles of long-chain polyunsaturated fatty acids in pregnancy, lactation and infancy: review of current knowledge and consensus recommendations," Journal of Perinatal Medicine, vol. 36, no. 1, pp. 5-14, 2008.

[42] EFSA Panel on Dietetic Products; Nutrition and Allergies (NDA), "Scientific opinion on dietary reference values for fats, including saturated fatty acids, polyunsaturated fatty acids, monounsaturated fatty acids, trans fatty acids, and cholesterol," The EFSA Journal, vol. 8, no. 3, article 1461, 2010.

[43] The Scientific Advisory Committee on Nutrition and Committee on Toxicity Advice on Benefits and Risks Related to Fish Consumption, SACN Advice on Fish Consumption: Benefits and Risks, The Scientific Advisory Committee on Nutrition and Committee on Toxicity Advice on Benefits and Risks Related to Fish Consumption, 2004.

[44] Health Council of the Netherlands, Guidelines for a Healthy Diet 2006, Publication no. 2006/21E, Health Council of the Netherlands, The Hague, the Netherlands, 2006.

[45] Health Council of the Netherlands, Dietary Reference Intakes: Energy, Proteins, Fats, and Digestible Carbohydrates, Health Council of the Netherlands, The Hague, The Netherlands, 2001, (Corrected Edition: June 2002).

[46] AFSSA, Apports nutritionnels conseillés pour la population française, Tec \& Doc Lavoisier Editions, 3rd edition, 2001.

[47] Conseil Supérieur de la Santé, Recommandations nutritionnelles pour la Belgique, Revision 2009, Publication du Conseil Superieur de la Sante no. 8 8309, Conseil Supérieur de la Santé, Brussels, Belgium, 2009.

[48] Sociedad Española de Nutrición Comunitaria (SENC), "Objetivos nutricionales para la población española," Revista Española de Nutrición Comunitaria, vol. 17, no. 4, pp. 178-199, 2011.

[49] National Health and Medical Research Council and Department of Health and Ageing, Nutrient Reference Values for Australia and New Zealand Including Recommended Dietary Intakes, Commonwealth of Australia, Canberra, Australia, 2006.

[50] Institute of Medicine, Food and Nutrition Board, Panel on Macronutrients, Panel on the Definition of Dietary Fiber, Subcommittee on Upper Reference Levels of Nutrients, Subcommittee on Interpretation and Uses of Dietary Reference Intakes, and the Standing Committee on the Scientific Evaluation of Dietary Reference Intakes, DRI Dietary Reference Intakes for Energy, Carbohydrate, Fiber, Fat, Fatty Acids, Cholesterol, Protein, and Amino Acids, Washington, DC, USA, The National Academies Press, 2005.

[51] J. P. Bantle, J. Wylie-Rosett, and A. L. Albright, "Nutrition recommendations and interventions for diabetes: a position statement of the American Diabetes Association," Diabetes Care, vol. 31, supplement 1, pp. S61-S78, 2007.

[52] P. M. Kris-Etherton, S. Innis, Ammerican Dietetic Assocition, and Dietitians of Canada, "Position of the American dietetic association and dietitians of Canada: dietary fatty acids," The Journal of the American Dietetic Association, vol. 107, no. 9, pp. 1599-1611, 2007.
[53] W. S. Harris, D. Mozaffarian, E. Rimm et al., "Omega-6 fatty acids and risk for cardiovascular disease: a science advisory from the American Heart Association Nutrition Subcommittee of the Council on Nutrition, Physical Activity, and Metabolism; Council on Cardiovascular Nursing; and Council on Epidemiology and Prevention," Circulation, vol. 119, no. 6, pp. 902-907, 2009.

[54] A. Leaf, C. M. Albert, M. Josephson et al., "Prevention of fatal arrhythmias in high-risk subjects by fish oil n-3 fatty acid intake," Circulation, vol. 112, no. 18, pp. 2762-2768, 2005.

[55] L. Tavazzi, A. P. Maggioni, R. Marchioli et al., "Effect of n-3 polyunsaturated fatty acids in patients with chronic heart failure (the GISSI-HF trial): a randomised, double-blind, placebocontrolled trial," The Lancet, vol. 372, no. 9645, pp. 1223-1230, 2008.

[56] P. Galan, E. Kesse-Guyot, S. Czernichow et al., "Effects of B vitamins and omega 3 fatty acids on cardiovascular diseases: a randomised placebo controlled trial," The British Medical Journal, vol. 341, Article ID c6273, 2010.

[57] M. Yokoyama, H. Origasa, M. Matsuzaki et al., "Effects of eicosapentaenoic acid on major coronary events in hypercholesterolaemic patients (JELIS): a randomised open-label, blinded endpoint analysis," The Lancet, vol. 369, no. 9567, pp. 1090-1098, 2007.

[58] B. Rauch, R. Schiele, S. Schneider et al., "OMEGA, a randomized, placebo-controlled trial to test the effect of highly purified omega-3 fatty acids on top of modern guidelineadjusted therapy after myocardial infarction," Circulation, vol. 122, no. 21, pp. 2152-2159, 2010.

[59] M. H. Raitt, W. E. Connor, C. Morris et al., "Fish oil supplementation and risk of ventricular tachycardia and ventricular fibrillation in patients with implantable defibrillators: a randomized controlled trial," The Journal of the American Medical Association, vol. 293, no. 23, pp. 2884-2891, 2005.

[60] I. A. Brouwer, P. L. Zock, A. J. Camm et al., "Effect of fish oil on ventricular tachyarrhythmia and death in patients with implantable cardioverter defibrillators: the Study on Omega3 Fatty acids and ventricular Arrhythmia (SOFA) randomized trial," The Journal of the American Medical Association, vol. 295, no. 22, pp. 2613-2619, 2006.

[61] R. Chowdhury, S. Warnakula, S. Kunutsor et al., "Association of dietary, circulating, and supplement fatty acids with coronary risk: a systematic review and meta-analysis," Annals of Internal Medicine, vol. 160, no. 6, pp. 398-406, 2014.

[62] E. C. Rizos, E. E. Ntzani, E. Bika, M. S. Kostapanos, and M. S. Elisaf, "Association between omega-3 fatty acid supplementation and risk of major cardiovascular disease events: a systematic review and meta-analysis," The Journal of the American Medical Association, vol. 308, no. 10, pp. 1024-1033, 2012.

[63] A. Belluzzi, C. Brignola, M. Campieri, A. Pera, S. Boschi, and M. Miglioli, "Effect of an enteric-coated fish-oil preparation on relapses in Crohn's disease," The New England Journal of Medicine, vol. 334, no. 24, pp. 1557-1560, 1996.

[64] E. Scorletti, L. Bhatia, K. G. McCormick et al., "Effects of purified eicosapentaenoic and docosahexaenoic acids in nonalcoholic fatty liver disease: results from the Welcome* study," Hepatology, vol. 60, no. 4, pp. 1211-1221, 2014.

[65] B. G. Feagan, W. J. Sandborn, U. Mittmann et al., “Omega-3 free fatty acids for the maintenance of remission in Crohn disease: the EPIC randomized controlled trials," Journal of the American Medical Association, vol. 299, no. 14, pp. 1690-1697, 2008. 
[66] W. F. Stenson, D. Cort, J. Rodgers et al., "Dietary supplementation with fish oil in ulcerative colitis," Annals of Internal Medicine, vol. 116, no. 8, pp. 609-614, 1992.

[67] N. Lasztity, J. Hamvas, L. Biró et al., "Effect of enterally administered n-3 polyunsaturated fatty acids in acute pancreatitisa prospective randomized clinical trial," Clinical Nutrition, vol. 24, no. 2, pp. 198-205, 2005.

[68] E. Cabré, M. Mañosa, and M. A. Gassull, "Omega-3 fatty acids and inflammatory bowel diseases-a systematic review," British Journal of Nutrition, vol. 107, no. 2, pp. S240-S252, 2012.

[69] J. Dyerberg, H. O. Bang, E. Stoffersen, S. Moncada, and J. R. Vane, "Eicosapentaenoic acid and prevention of thrombosis and atherosclerosis?” The Lancet, vol. 2, no. 8081, pp. 117-119, 1978.

[70] J. X. Kang and A. Leaf, "Effects of long-chain polyunsaturated fatty acids on the contraction of neonatal rat cardiac myocytes," Proceedings of the National Academy of Sciences of the United States of America, vol. 91, no. 21, pp. 9886-9890, 1994.

[71] K. H. Weylandt, J. X. Kang, and A. Leaf, "Polyunsaturated fatty acids exert antiarrhythmic actions as free acids rather than in phospholipids," Lipids, vol. 31, no. 9, pp. 977-982, 1996.

[72] G. E. Billman, J. X. Kang, and A. Leaf, "Prevention of ischemiainduced cardiac sudden death by n-3 polyunsaturated fatty acids in dogs," Lipids, vol. 32, no. 11, pp. 1161-1168, 1997.

[73] P. M. Kris-Etherton, W. S. Harris, and L. J. Appel, "Fish consumption, fish oil, omega-3 fatty acids, and cardiovascular disease," Circulation, vol. 106, no. 21, pp. 2747-2757, 2002.

[74] G. Taubes, "The science of obesity: what do we really know about what makes us fat? An essay by Gary Taubes," British Medical Journal, vol. 346, no. 7904, Article ID f1050, 2013.

[75] W. S. Harris and G. C. Shearer, "Omega-6 fatty acids and cardiovascular disease: friend or foe?" Circulation, 2014.

[76] M. de Lorgeril, P. Salen, P. Defaye, and M. Rabaeus, "Recent findings on the health effects of omega-3 fatty acids and statins, and their interactions: do statins inhibit omega-3?" BMC Medicine, vol. 11, no. 1, article 5, 2013.

[77] W. S. Harris and C. von Schacky, "The Omega-3 Index: a new risk factor for death from coronary heart disease?" Preventive Medicine, vol. 39, no. 1, pp. 212-220, 2004.

[78] W. S. Harris, "The omega-3 index as a risk factor for coronary heart disease," The American Journal of Clinical Nutrition, vol. 87, no. 6, pp. 1997S-2002S, 2008.

[79] R. Fischer, A. Konkel, H. Mehling et al., "Dietary omega-3 fatty acids modulate the eicosanoid profile in man primarily via the CYP-epoxygenase pathway," The Journal of Lipid Research, vol. 55, no. 6, pp. 1150-1164, 2014.

[80] K. H. Weylandt, C.-Y. Chiu, B. Gomolka, S. F. Waechter, and B. Wiedenmann, "Omega-3 fatty acids and their lipid mediators: towards an understanding of resolvin and protectin formation," Prostaglandins \& Other Lipid Mediators, vol. 97, no. 3-4, pp. 7382, 2012.

[81] J. R. Falck, G. Wallukat, N. Puli et al., "17(R),18(S)-Epoxyeicosatetraenoic acid, a potent eicosapentaenoic acid (EPA) derived regulator of cardiomyocyte contraction: structure-activity relationships and stable analogues," Journal of Medicinal Chemistry, vol. 54, no. 12, pp. 4109-4118, 2011.

[82] J. Endo, M. Sano, Y. Isobe et al., "18-HEPE, an n-3 fatty acid metabolite released by macrophages, prevents pressure overload-induced maladaptive cardiac remodeling," Journal of Experimental Medicine, vol. 211, no. 8, pp. 1673-1687, 2014.

[83] M. Anti, G. Marra, F. Armelao et al., "Effect of omega-3 fatty acids on rectal mucosal cell proliferation in subjects at risk for colon cancer," Gastroenterology, vol. 103, no. 3, pp. 883-891, 1992.

[84] H.-P. Bartram, A. Gostner, W. Scheppach et al., "Effects of fish oil on rectal cell proliferation, mucosal fatty acids, and prostaglandin E2 release in healthy subjects," Gastroenterology, vol. 105, no. 5, pp. 1317-1322, 1993.

[85] M. Anti, F. Armelao, G. Marra et al., "Effects of different doses of fish oil on rectal cell proliferation in patients with sporadic colonic adenomas," Gastroenterology, vol. 107, no. 6, pp. 17091718, 1994.

[86] H.-P. Bartram, A. Gostner, B. S. Reddy et al., "Missing antiproliferative effect of fish oil on rectal epithelium in healthy volunteers consuming a high-fat diet: potential role of the n3:n-6 fatty acid ratio," European Journal of Cancer Prevention, vol. 4, no. 3, pp. 231-237, 1995.

[87] Y.-C. Huang, J. M. Jessup, R. A. Forse et al., "n-3 Fatty acids decrease colonic epithelial cell proliferation in high-risk bowel mucosa," Lipids, vol. 31, no. 3, supplement, pp. S313-S317, 1996.

[88] J. M. Gee, M. Watson, J. A. Matthew et al., "Consumption of fish oil leads to prompt incorporation of eicosapentaenoic acid into colonic mucosa of patients prior to surgery for colorectal cancer, but has no detectable effect on epithelial cytokinetics," The Journal of Nutrition, vol. 129, no. 10, pp. 1862-1865, 1999.

[89] J. Cheng, K. Ogawa, K. Kuriki et al., "Increased intake of n3 polyunsaturated fatty acids elevates the level of apoptosis in the normal sigmoid colon of patients polypectomized for adenomas/tumors," Cancer Letters, vol. 193, no. 1, pp. 17-24, 2003.

[90] E. D. Courtney, S. Matthews, C. Finlayson et al., "Eicosapentaenoic acid (EPA) reduces crypt cell proliferation and increases apoptosis in normal colonic mucosa in subjects with a history of colorectal adenomas," International Journal of Colorectal Disease, vol. 22, no. 7, pp. 765-776, 2007.

[91] N. J. West, S. K. Clark, R. K. S. Phillips et al., "Eicosapentaenoic acid reduces rectal polyp number and size in familial adenomatous polyposis," Gut, vol. 59, no. 7, pp. 918-925, 2010.

[92] A. J. Cockbain, M. Volpato, A. D. Race et al., "Anticolorectal cancer activity of the omega-3 polyunsaturated fatty acid eicosapentaenoic acid," Gut, vol. 63, no. 11, pp. 1760-1768, 2014.

[93] G. K. Pot, G. Majsak-Newman, A. Geelen et al., "Fish consumption and markers of colorectal cancer risk: a multicenter randomized controlled trial," The American Journal of Clinical Nutrition, vol. 90, no. 2, pp. 354-361, 2009.

[94] G. K. Pot, A. Geelen, G. Majsak-Newman et al., "Increased consumption of fatty and lean fish reduces serum C-reactive protein concentrations but not inflammation markers in feces and in colonic biopsies," Journal of Nutrition, vol. 140, no. 2, pp. 371-376, 2010.

[95] M. C. Mocellin, J. D. A. Pastore E Silva, C. D. Q. Camargo et al., "Fish oil decreases C-reactive protein/albumin ratio improving nutritional prognosis and plasma fatty acid profile in colorectal cancer patients," Lipids, vol. 48, no. 9, pp. 879-888, 2013.

[96] H. J. Murff, M. J. Shrubsole, Q. Cai et al., "Dietary intake of PUFAs and colorectal polyp risk," The American Journal of Clinical Nutrition, vol. 95, no. 3, pp. 703-712, 2012.

[97] E. D. Kantor, J. W. Lampe, U. Peters, T. L. Vaughan, and E. White, "Long-chain omega-3 polyunsaturated fatty acid intake and risk of colorectal cancer," Nutrition and Cancer, vol. 66, no. 4, pp. 716-727, 2014.

[98] M. Song, A. T. Chan, C. S. Fuchs et al., "Dietary intake of fish, $\omega$ 3 and $\omega-6$ fatty acids and risk of colorectal cancer: a prospective 
study in U.S. men and women," International Journal of Cancer, vol. 135, no. 10, pp. 2413-2423, 2014.

[99] N. Habermann, C. M. Ulrich, A. Lundgreen et al., "PTGS1, PTGS2, ALOX5, ALOX12, ALOX15, and FLAP SNPs: interaction with fatty acids in colon cancer and rectal cancer," Genes and Nutrition, vol. 8, no. 1, pp. 115-126, 2013.

[100] S. Wu, B. Feng, K. Li et al., "Fish consumption and colorectal cancer risk in humans: a systematic review and meta-analysis," The American Journal of Medicine, vol. 125, no. 6, pp. 551-559, 2012.

[101] M. Gerber, "Background review paper on total fat, fatty acid intake and cancers," Annals of Nutrition and Metabolism, vol. 55, no. 1-3, pp. 140-161, 2009.

[102] M. Gerber, "Omega-3 fatty acids and cancers: a systematic update review of epidemiological studies," British Journal of Nutrition, vol. 107, no. 2, pp. S228-S239, 2012.

[103] K. Mina, L. Fritschi, K. C. Johnson et al., "An inverse association between preserved fish and prostate cancer: results from a population-based case-control study in Canada," Nutrition and Cancer, vol. 60, no. 2, pp. 222-226, 2008.

[104] C. D. Williams, B. M. Whitley, C. Hoyo et al., "A high ratio of dietary n-6/n-3 polyunsaturated fatty acids is associated with increased risk of prostate cancer," Nutrition Research, vol. 31, no. 1, pp. 1-8, 2011.

[105] F. L. Crowe, N. E. Allen, P. N. Appleby et al., "Fatty acid composition of plasma phospholipids and risk of prostate cancer in a case-control analysis nested within the European Prospective Investigation into Cancer and Nutrition," The American Journal of Clinical Nutrition, vol. 88, no. 5, pp. 1353-1363, 2008.

[106] V. Fradet, L. Cheng, G. Casey, and J. S. Witte, "Dietary omega-3 fatty acids, cyclooxygenase-2 genetic variation, and aggressive prostate cancer risk," Clinical Cancer Research, vol. 15, no. 7, pp. 2559-2566, 2009.

[107] A. R. Kristal, J. H. Cohen, P. Qu, and J. L. Stanford, "Associations of energy, fat, calcium, and vitamin D with prostate cancer risk," Cancer Epidemiology Biomarkers and Prevention, vol. 11, no. 8, pp. 719-725, 2002.

[108] J. E. Chavarro, M. J. Stampfer, M. N. Hall, H. D. Sesso, and J. Ma, "A 22-y prospective study of fish intake in relation to prostate cancer incidence and mortality," The American Journal of Clinical Nutrition, vol. 88, no. 5, pp. 1297-1303, 2008.

[109] S.-Y. Park, L. R. Wilkens, S. M. Henning et al., "Circulating fatty acids and prostate cancer risk in a nested case-control study: the Multiethnic Cohort," Cancer Causes and Control, vol. 20, no. 2, pp. 211-223, 2009.

[110] J. E. Torfadottir, U. A. Valdimarsdottir, L. A. Mucci et al., "Consumption of fish products across the lifespan and prostate cancer risk," PLoS ONE, vol. 8, no. 4, Article ID e59799, 2013.

[111] S. Männistö, P. Pietinen, M. J. Virtanen et al., "Fatty acids and risk of prostate cancer in a nested case-control study in male smokers," Cancer Epidemiology, Biomarkers and Prevention, vol. 12, no. 12, pp. 1422-1428, 2003.

[112] M. E. Chua, M. C. D. Sio, M. C. Sorongon, and M. L. Morales Jr., "The relevance of serum levels of long chain omega-3 polyunsaturated fatty acids and prostate cancer risk: a metaanalysis," Canadian Urological Association Journal, vol. 7, no. 56, pp. E333-E343, 2013.

[113] M. K. Sorongon-Legaspi, M. Chua, M. C. Sio, and M. Morales, "Blood level omega-3 Fatty acids as risk determinant molecular biomarker for prostate cancer," Prostate Cancer, vol. 2013, Article ID 875615, 15 pages, 2013.
[114] D. Patel, K. Thevenet-Morrison, and E. van Wijngaarden, "Omega-3 polyunsaturated fatty acid intake through fish consumption and prostate specific antigen level: results from the 2003 to 2010 national health and examination survey," Prostaglandins, Leukotrienes and Essential Fatty Acids, vol. 91, no. 4, pp. 155-160, 2014.

[115] S. Harvei, K. S. Bjerve, S. Tretli, E. Jellum, T. E. Robsahm, and L. Vatten, "Prediagnostic level of fatty acids in serum phospholipids: omega-3 and omega- 6 fatty acids and the risk of prostate cancer," International Journal of Cancer, vol. 71, no. 4, pp. 545-551, 1997.

[116] K. M. Szymanski, D. C. Wheeler, and L. A. Mucci, "Fish consumption and prostate cancer risk: a review and metaanalysis," The American Journal of Clinical Nutrition, vol. 92, no. 5, pp. 1223-1233, 2010.

[117] I. A. Brouwer, "Omega-3 PUFA: good or bad for prostate cancer?" Prostaglandins Leukotrienes and Essential Fatty Acids, vol. 79, no. 3-5, pp. 97-99, 2008.

[118] B. Samuelsson, "Prostaglandins, thromboxanes, and leukotrienes: formation and biological roles," Harvey Lectures, vol. 75, pp. $1-40,1979$.

[119] S. Moncada, S. H. Ferreira, and J. R. Vane, "Prostaglandins, aspirin like drugs and the oedema of inflammation," Nature, vol. 246, no. 5430, pp. 217-219, 1973.

[120] B. Gopinath, A. E. Buyken, V. M. Flood, M. Empson, E. Rochtchina, and P. Mitchell, "Consumption of polyunsaturated fatty acids, fish, and nuts and risk of inflammatory disease mortality," The American Journal of Clinical Nutrition, vol. 93, no. 5, pp. 1073-1079, 2011.

[121] H. F. Turk, J. M. Monk, Y.-Y. Fan, E. S. Callaway, B. Weeks, and R. S. Chapkin, "Inhibitory effects of omega-3 fatty acids on injury-induced epidermal growth factor receptor transactivation contribute to delayed wound healing," American Journal of Physiology-Cell Physiology, vol. 304, no. 9, pp. C905-C917, 2013.

[122] C. V. Whiting, P. W. Bland, and J. F. Tarlton, "Dietary n-3 polyunsaturated fatty acids reduce disease and colonic proinflammatory cytokines in a mouse model of colitis," Inflammatory Bowel Diseases, vol. 11, no. 4, pp. 340-349, 2005.

[123] S. Ghosh, D. DeCoffe, K. Brown et al., "Fish oil attenuates omega-6 polyunsaturated fatty acid-induced dysbiosis and infectious colitis but impairs LPS dephosphorylation activity causing sepsis," PLoS ONE, vol. 8, no. 2, Article ID e55468, 2013.

[124] F. G. Campos, D. L. Waitzberg, A. Habr-Gama et al., "Impact of parenteral n-3 fatty acids on experimental acute colitis," British Journal of Nutrition, vol. 87, no. 1, pp. S83-S88, 2002.

[125] J. I. Fenton, N. G. Hord, S. Ghosh, and E. A. Gurzell, "Immunomodulation by dietary long chain omega-3 fatty acids and the potential for adverse health outcomes," Prostaglandins Leukotrienes and Essential Fatty Acids, vol. 89, no. 6, pp. 379390, 2013.

[126] H. Matsunaga, R. Hokari, C. Kurihara et al., "Omega-3 fatty acids exacerbate DSS-induced colitis through decreased adiponectin in colonic subepithelial myofibroblasts," Inflammatory Bowel Diseases, vol. 14, no. 10, pp. 1348-1357, 2008.

[127] H. L. Woodworth, S. J. McCaskey, D. M. Duriancik et al., "Dietary fish oil alters $\mathrm{T}$ lymphocyte cell populations and exacerbates disease in a mouse model of inflammatory colitis," Cancer Research, vol. 70, no. 20, pp. 7960-7969, 2010.

[128] R. A. F. Hegazi, R. S. Saad, H. Mady, L. E. Matarese, S. O’Keefe, and H. M. Kandil, "Dietary fatty acids modulate chronic colitis, 
colitis-associated colon neoplasia and COX-2 expression in IL10 knockout mice," Nutrition, vol. 22, no. 3, pp. 275-282, 2006.

[129] R. Kühn, J. Löhler, D. Rennick, K. Rajewsky, and W. Müller, "Interleukin-10-deficient mice develop chronic enterocolitis," Cell, vol. 75, no. 2, pp. 263-274, 1993.

[130] R. S. Chapkin, L. A. Davidson, L. Ly, B. R. Weeks, J. R. Lupton, and D. N. McMurray, "Immunomodulatory effects of (n-3) fatty acids: putative link to inflammation and colon cancer," Journal of Nutrition, vol. 137, supplement 1, pp. 200S-204S, 2007.

[131] J. X. Kang, J. Wang, L. Wu, and Z. B. Kang, "Transgenic mice: fat-1 mice convert n-6 to n-3 fatty acids," Nature, vol. 427, no. 6974, p. 504, 2004.

[132] C. A. Hudert, K. H. Weylandt, Y. Lu et al., "Transgenic mice rich in endogenous omega-3 fatty acids are protected from colitis," Proceedings of the National Academy of Sciences of the United States of America, vol. 103, no. 30, pp. 11276-11281, 2006.

[133] J. M. Monk, Q. Jia, E. Callaway et al., “Th17 cell accumulation is decreased during chronic experimental colitis by (n-3) PUFA in fat-1 mice," Journal of Nutrition, vol. 142, no. 1, pp. 117-124, 2012.

[134] Q. Jia, J. R. Lupton, R. Smith et al., "Reduced colitis-associated colon cancer in fat- 1 (n-3 fatty acid desaturase) transgenic mice," Cancer Research, vol. 68, no. 10, pp. 3985-3991, 2008.

[135] J. Nowak, K. H. Weylandt, P. Habbel et al., "Colitis-associated colon tumorigenesis is suppressed in transgenic mice rich in endogenous n-3 fatty acids," Carcinogenesis, vol. 28, no. 9, pp. 1991-1995, 2007.

[136] C. Schmöcker, K. H. Weylandt, L. Kahlke et al., "Omega3 fatty acids alleviate chemically induced acute hepatitis by suppression of cytokines," Hepatology, vol. 45, no. 4, pp. 864869, 2007.

[137] K. H. Weylandt, A. Nadolny, L. Kahlke et al., "Reduction of inflammation and chronic tissue damage by omega-3 fatty acids in fat-1 transgenic mice with pancreatitis," Biochimica et Biophysica Acta - Molecular Basis of Disease, vol. 1782, no. 11, pp. 634-641, 2008.

[138] H. Teague, C. J. Fhaner, M. Harris, D. M. Duriancik, G. E. Reid, and S. R. Shaikh, "N-3 PUFAs enhance the frequency of murine B-cell subsets and restore the impairment of antibody production to a T-independent antigen in obesity," Journal of Lipid Research, vol. 54, no. 11, pp. 3130-3138, 2013.

[139] C. N. Serhan, S. Hong, K. Gronert et al., "Resolvins: a family of bioactive products of omega-3 fatty acid transformation circuits initiated by aspirin treatment that counter proinflammation signals," The Journal of Experimental Medicine, vol. 196, no. 8, pp. 1025-1037, 2002.

[140] M. Arita, F. Bianchini, J. Aliberti et al., "Stereochemical assignment, antiinflammatory properties, and receptor for the omega3 lipid mediator resolvin E1," The Journal of Experimental Medicine, vol. 201, no. 5, pp. 713-722, 2005.

[141] C. Y. Chiu, B. Gomolka, C. Dierkes et al., "Omega-6 docosapentaenoic acid-derived resolvins and 17- hydroxydocosahexaenoic acid modulate macrophage function and alleviate experimental colitis," Inflammation Research, vol. 61, no. 9, pp. 967-976, 2012.

[142] T. Köhnke, B. Gomolka, S. Bilal et al., "Acetylsalicylic acid reduces the severity of dextran sodium sulfate-induced colitis and increases the formation of anti-inflammatory lipid mediators," BioMed Research International, vol. 2013, Article ID 748160, 10 pages, 2013.

[143] K. H. Weylandt, L. F. Krause, B. Gomolka et al., "Suppressed liver tumorigenesis in fat-1 mice with elevated omega-3 fatty acids is associated with increased omega- 3 derived lipid mediators and reduced TNF- $\alpha$," Carcinogenesis, vol. 32, no. 6, pp. 897903, 2011.

[144] A. F. Bento, R. F. Claudino, R. C. Dutra, R. Marcon, and J. B. Calixto, "Omega-3 fatty acid-derived mediators 17(R)hydroxy docosahexaenoic acid, aspirin-triggered resolvin D1 and resolvin D2 prevent experimental colitis in mice," Journal of Immunology, vol. 187, no. 4, pp. 1957-1969, 2011.

[145] A. González-Périz, A. Planagumà, K. Gronert et al., "Docosahexaenoic acid (DHA) blunts liver injury by conversion to protective lipid mediators: protectin D1 and 17S-hydroxy-DHA," The FASEB Journal, vol. 20, no. 14, pp. 2537-2539, 2006.

[146] A. Neuhofer, M. Zeyda, D. Mascher et al., "Impaired local production of proresolving lipid mediators in obesity and 17HDHA as a potential treatment for obesity-associated inflammation," Diabetes, vol. 62, no. 6, pp. 1945-1956, 2013.

[147] A. Ariel and C. N. Serhan, "Resolvins and protectins in the termination program of acute inflammation," Trends in Immunology, vol. 28, no. 4, pp. 176-183, 2007.

[148] J. Griffitts, D. Saunders, Y. A. Tesiram et al., "Non-mammalian fat-1 gene prevents neoplasia when introduced to a mouse hepatocarcinogenesis model. Omega-3 fatty acids prevent liver neoplasia," Biochimica et Biophysica Acta, vol. 1801, no. 10, pp. 1133-1144, 2010.

[149] K. Lim, C. Han, Y. Dai, M. Shen, and T. Wu, "Omega-3 polyunsaturated fatty acids inhibit hepatocellular carcinoma cell growth through blocking beta-catenin and cyclooxygenase2," Molecular Cancer Therapeutics, vol. 8, no. 11, pp. 3046-3055, 2009.

[150] N. Sawada, M. Inoue, M. Iwasaki et al., "Consumption of n-3 fatty acids and fish reduces risk of hepatocellular carcinoma," Gastroenterology, vol. 142, no. 7, pp. 1468-1475, 2012.

[151] J. A. Baron, B. F. Cole, R. S. Sandler et al., "A randomized trial of aspirin to prevent colorectal adenomas," The New England Journal of Medicine, vol. 348, no. 10, pp. 891-899, 2003.

[152] P. M. Rothwell, M. Wilson, C. E. Elwin et al., "Long-term effect of aspirin on colorectal cancer incidence and mortality: 20-year follow-up of five randomised trials," The Lancet, vol. 376, no. 9754, pp. 1741-1750, 2010.

[153] M. A. Hull, A. C. Sandell, A. A. Montgomery et al., "A randomized controlled trial of eicosapentaenoic acid and/or aspirin for colorectal adenoma prevention during colonoscopic surveillance in the NHS Bowel Cancer Screening Programme (The seAFOod Polyp Prevention Trial): study protocol for a randomized controlled trial," Trials, vol. 14, no. 1, article 237, 2013.

[154] S. Serini, E. Piccioni, and G. Calviello, “ $\omega$-3 PUFAs and colon cancer: experimental studies and human interventional trials," in Dietary Omega-3 Polyunsaturated Fatty Acids and Cancer, G. Calviello and S. Serini, Eds., vol. 1 of Diet and Cancer, pp. 67-89, Springer, Dordrecht, The Netherlands, 2010.

[155] S. Serini, E. Fasano, E. Piccioni, A. R. M. Cittadini, and G. Calviello, "Differential anti-cancer effects of purified EPA and DHA and possible mechanisms involved," Current Medicinal Chemistry, vol. 18, no. 26, pp. 4065-4075, 2011.

[156] S. Serini, E. Fasano, L. Celleno, A. Cittadini, and G. Calviello, "Potential of long-chain n-3 polyunsaturated fatty acids in melanoma prevention," Nutrition Reviews, vol. 72, no. 4, pp. 255-266, 2014.

[157] K. Triff, E. Kim, and R. S. Chapkin, "Chemoprotective epigenetic mechanisms in a colorectal cancer model: modulation 
by n-3 PUFA in combination with fermentable fiber," Current Pharmacology Reports, vol. 1, no. 1, pp. 11-20, 2015.

[158] R. S. Chapkin, J. Seo, D. N. McMurray, and J. R. Lupton, "Mechanisms by which docosahexaenoic acid and related fatty acids reduce colon cancer risk and inflammatory disorders of the intestine," Chemistry and Physics of Lipids, vol. 153, no. 1, pp. 14-23, 2008.

[159] R. S. Chapkin, V. DeClercq, E. Kim, N. R. Fuentes, and Y. Y. Fan, "Mechanisms by which pleiotropic amphiphilic n-3 PUFA reduce colon cancer risk," Current Colorectal Cancer Reports, vol. 10, no. 4, pp. 442-452, 2014.

[160] W. Stillwell and S. R. Wassall, "Docosahexaenoic acid: membrane properties of a unique fatty acid," Chemistry and Physics of Lipids, vol. 126, no. 1, pp. 1-27, 2003.

[161] E. Fasano, S. Serini, E. Piccioni et al., "DHA induces apoptosis by altering the expression and cellular location of GRP78 in colon cancer cell lines," Biochimica et Biophysica Acta: Molecular Basis of Disease, vol. 1822, no. 11, pp. 1762-1772, 2012.

[162] M. Ni, Y. Zhang, and A. S. Lee, "Beyond the endoplasmic reticulum: atypical GRP78 in cell viability, signalling and therapeutic targeting," Biochemical Journal, vol. 434, no. 2, pp. 181-188, 2011.

[163] R. A. Siddiqui, K. Harvey, and W. Stillwell, "Anticancer properties of oxidation products of docosahexaenoic acid," Chemistry and Physics of Lipids, vol. 153, no. 1, pp. 47-56, 2008.

[164] D.-S. Im, "Omega-3 fatty acids in anti-inflammation (proresolution) and GPCRs," Progress in Lipid Research, vol. 51, no. 3, pp. 232-237, 2012.

[165] P. C. Calder, "Marine omega-3 fatty acids and inflammatory processes: effects, mechanisms and clinical relevance," Biochimica et Biophysica Acta, vol. 1851, no. 4, pp. 469-484, 2015.

[166] N. Sadli, M. L. Ackland, D. de Mel, A. J. Sinclair, and C. Suphioglu, "Effects of zinc and DHA on the epigenetic regulation of human neuronal cells," Cellular Physiology and Biochemistry, vol. 29, no. 1-2, pp. 87-98, 2012.

[167] H.-S. Lee, A. Barraza-Villarreal, H. Hernandez-Vargas et al., "Modulation of DNA methylation states and infant immune system by dietary supplementation with $\omega$-3 PUFA during pregnancy in an intervention study," The American Journal of Clinical Nutrition, vol. 98, no. 2, pp. 480-487, 2013.

[168] M. Amarasekera, P. Noakes, D. Strickland, R. Saffery, D. J. Martino, and S. L. Prescott, "Epigenome-wide analysis of neonatal $\mathrm{CD}^{+}$T-cell DNA methylation sites potentially affected by maternal fish oil supplementation," Epigenetics, vol. 9, no. 12, pp. 1570-1576, 2014.

[169] M. Dimri, P. V. Bommi, A. A. Sahasrabuddhe, J. D. Khandekar, and G. P. Dimri, "Dietary omega-3 polyunsaturated fatty acids suppress expression of EZH2 in breast cancer cells," Carcinogenesis, vol. 31, no. 3, pp. 489-495, 2010.

[170] Y. Cho, N. D. Turner, L. A. Davidson, R. S. Chapkin, R. J. Carroll, and J. R. Lupton, "A chemoprotective fish oil/pectin diet enhances apoptosis via $\mathrm{Bcl}-2$ promoter methylation in rat azoxymethane-induced carcinomas," Experimental Biology and Medicine, vol. 237, no. 12, pp. 1387-1393, 2012.

[171] Y. Cho, N. D. Turner, L. A. Davidson, R. S. Chapkin, R. J. Carroll, and J. R. Lupton, "Colon cancer cell apoptosis is induced by combined exposure to the $\mathrm{n}-3$ fatty acid docosahexaenoic acid and butyrate through promoter methylation," Experimental Biology and Medicine, vol. 239, no. 3, pp. 302-310, 2014.

[172] A. J. Cockbain, G. J. Toogood, and M. A. Hull, "Omega-3 polyunsaturated fatty acids for the treatment and prevention of colorectal cancer," Gut, vol. 61, no. 1, pp. 135-149, 2012.
[173] A. Bommareddy, X. Zhang, D. Schrader et al., "Effects of dietary flaxseed on intestinal tumorigenesis in $\mathrm{Apc}^{\mathrm{Min}}$ mouse," Nutrition and Cancer, vol. 61, no. 2, pp. 276-283, 2009.

[174] G. Piazzi, G. D’Argenio, A. Prossomariti et al., "Eicosapentaenoic acid free fatty acid prevents and suppresses colonic neoplasia in colitis-associated colorectal cancer acting on Notch signaling and gut microbiota," International Journal of Cancer, vol. 135, no. 9, pp. 2004-2013, 2014.

[175] P. Griffini, O. Fehres, L. Klieverik et al., "Dietary omega-3 polyunsaturated fatty acids promote colon carcinoma metastasis in rat liver," Cancer Research, vol. 58, no. 15, pp. 3312-3319, 1998.

[176] T. Yang, S. Fang, H.-X. Zhang et al., "N-3 PUFAs have antiproliferative and apoptotic effects on human colorectal cancer stemlike cells in vitro," Journal of Nutritional Biochemistry, vol. 24, no. 5, pp. 744-753, 2013.

[177] F. de Carlo, T. R. Witte, W. E. Hardman, and P. P. Claudio, "Omega-3 eicosapentaenoic acid decreases CD133 colon cancer stem-like cell marker expression while increasing sensitivity to chemotherapy," PLoS ONE, vol. 8, no. 7, Article ID e69760, 2013.

[178] A. Vasudevan, Y. Yu, S. Banerjee et al., "Omega-3 fatty acid is a potential preventive agent for recurrent colon cancer," Cancer Prevention Research, vol. 7, no. 11, pp. 1138-1148, 2014.

[179] A. Zeuner, M. Todaro, G. Stassi, and R. De Maria, "Colorectal cancer stem cells: from the crypt to the clinic," Cell Stem Cell, vol. 15, no. 6, pp. 692-705, 2014.

[180] N. Barker, J. H. van Es, J. Kuipers et al., "Identification of stem cells in small intestine and colon by marker gene Lgr5," Nature, vol. 449, no. 7165, pp. 1003-1007, 2007.

[181] P. Dalerba, S. J. Dylla, I. K. Park et al., "Phenotypic characterization of human colorectal cancer stem cells," Proceedings of the National Academy of Sciences of the United States of America, vol. 104, no. 24, pp. 10158-10163, 2007.

[182] L. Ricci-Vitiani, D. G. Lombardi, E. Pilozzi et al., "Identification and expansion of human colon-cancer-initiating cells," Nature, vol. 445, no. 7123, pp. 111-115, 2007.

[183] P. D. Biondo, D. N. Brindley, M. B. Sawyer, and C. J. Field, "The potential for treatment with dietary long-chain polyunsaturated n-3 fatty acids during chemotherapy," Journal of Nutritional Biochemistry, vol. 19, no. 12, pp. 787-796, 2008.

[184] G. Calviello, S. Serini, E. Piccioni, and G. Pessina, "Antineoplastic effects of N-3 polyunsaturated fatty acids in combination with drugs and radiotherapy: preventive and therapeutic strategies," Nutrition and Cancer, vol. 61, no. 3, pp. 287-301, 2009.

[185] J. Wang, T. Luo, S. Li, and J. Zhao, “The powerful applications of polyunsaturated fatty acids in improving the therapeutic efficacy of anticancer drugs," Expert Opinion on Drug Delivery, vol. 9, no. 1, pp. 1-7, 2012.

[186] G. Calviello, P. Palozza, P. Franceschelli, and G. M. Bartoli, "Low-dose eicosapentaenoic or docosahexaenoic acid administration modifies fatty acid composition and does not affect susceptibility to oxidative stress in rat erythrocytes and tissues," Lipids, vol. 32, no. 10, pp. 1075-1083, 1997.

[187] S. S. Taneja, "Re: plasma phospholipid fatty acids and prostate cancer risk in the SELECT trial," The Journal of Urology, vol. 191, no. 3, p. 658, 2014.

[188] K. El-Bayoumy, H. Thompson, and A. Manni, "RE: plasma phospholipid fatty acids and prostate cancer risk in the SELECT trial," Journal of the National Cancer Institute, vol. 106, no. 4, Article ID dju017, 2014. 
[189] J. T. Brenna, G. C. Burdge, M. A. Crawford et al., "RE: plasma phospholipid fatty acids and prostate cancer risk in the SELECT trial," Journal of the National Cancer Institute, vol. 106, no. 4, Article ID dju015, 2014.

[190] M. McCulloch, E. Alvarez, R. Gendreau, S. Haney, J. Harrelson, and R. Luo, "RE: serum phospholipid fatty acids and prostate cancer risk in the SELECT trial," Journal of the National Cancer Institute, vol. 106, no. 4, Article ID dju024, 2014.

[191] W. S. Harris and M. H. Davidson, "RE: plasma phospholipid fatty acids and prostate cancer risk in the SELECT trial," Journal of the National Cancer Institute, vol. 106, no. 4, Article ID dju019, 2014.

[192] J. E. Torfadottir, M. J. Stampfer, L. A. Mucci, and E. L. Giovannucci, "RE: plasma phospholipid fatty acids and prostate cancer risk in the SELECT trial," Journal of the National Cancer Institute, vol. 106, no. 4, Article ID dju018, 2014.

[193] M. F. McCarty, J. J. Dinicolantonio, C. J. Lavie, and J. H. O'Keefe, "RE: plasma phospholipid fatty acids and prostate cancer risk in the SELECT trial," Journal of the National Cancer Institute, vol. 106, no. 4, Article ID dju014, 2014.

[194] L. G. Cleland, S. M. Proudman, and M. J. James, "RE: plasma phospholipid fatty acids and prostate cancer risk in the SELECT trial," Journal of the National Cancer Institute, vol. 106, no. 4, Article ID dju022, 2014.

[195] S. Tokudome, R. Ando, Y. Ichikawa et al., "RE: plasma phospholipid fatty acids and prostate cancer risk in the SELECT trial," Journal of the National Cancer Institute, vol. 106, no. 4, Article ID dju020, 2014.

[196] P. O. Eser, J. P. Vanden Heuvel, J. Araujo, and J. T. Thompson, "Marine- and plant-derived $\omega$-3 fatty acids differentially regulate prostate cancer cell proliferation," Molecular and Clinical Oncology, vol. 1, no. 3, pp. 444-452, 2013.

[197] S. A. Apte, D. A. Cavazos, K. A. Whelan, and L. A. Degraffenried, "A low dietary ratio of omega- 6 to omega-3 fatty acids may delay progression of prostate cancer," Nutrition and Cancer, vol. 65, no. 4, pp. 556-562, 2013.

[198] P. Astorg, "Dietary $n-6$ and $n-3$ polyunsaturated fatty acids and prostate cancer risk: a review of epidemiological and experimental evidence," Cancer Causes \& Control, vol. 15, no. 4, pp. 367-386, 2004.

[199] M. D. Brown, C. A. Hart, E. Gazi, S. Bagley, and N. W. Clarke, "Promotion of prostatic metastatic migration towards human bone marrow stoma by Omega 6 and its inhibition by Omega 3 PUFAs," British Journal of Cancer, vol. 94, no. 6, pp. 842-853, 2006.

[200] D. Ruan and S. P. So, "Prostaglandin $\mathrm{E}_{2}$ produced by inducible COX-2 and mPGES-1 promoting cancer cell proliferation in vitro and in vivo," Life Sciences, vol. 116, no. 1, pp. 43-50, 2014.

[201] S. Larré, N. Tran, C. Fan et al., "PGE2 and LTB4 tissue levels in benign and cancerous prostates," Prostaglandins and Other Lipid Mediators, vol. 87, no. 1-4, pp. 14-19, 2008.

[202] T. M. Brasky, C. Till, E. White et al., "Serum phospholipid fatty acids and prostate cancer risk: results from the prostate cancer prevention trial," The American Journal of Epidemiology, vol. 173, no. 12, pp. 1429-1439, 2011.

[203] R. Sosnowski and J. Zawistowski, "Re: plasma phospholipid fatty acids and prostate cancer risk in the SELECT trial," European Urology, vol. 65, no. 5, p. 1012, 2014.

[204] K. Chow and D. G. Murphy, "Words of wisdom. Re: plasma phospholipid fatty acids and prostate cancer risk in the SELECT trial," European Urology, vol. 64, no. 6, pp. 1015-1016, 2013.
[205] V. Kipnis, A. F. Subar, D. Midthune et al., "Structure of dietary measurement error: results of the OPEN biomarker study," American Journal of Epidemiology, vol. 158, no. 1, pp. 14-21, 2003.

[206] D. J. Hunter, E. B. Rimm, F. M. Sacks et al., "Comparison of measures of fatty acid intake by subcutaneous fat aspirate, food frequency questionnaire, and diet records in a free-living population of US men," The American Journal of Epidemiology, vol. 135, no. 4, pp. 418-427, 1992.

[207] Y. Kimura, " $\omega-3$ PUFAs and colon cancer: epidemiological studies," in Dietary Omega-3 Polyunsaturated Fatty Acids and Cancer, G. Calviello and S. Serini, Eds., pp. 41-66, Springer, Dordrecht, The Netherlands, 2010.

[208] K. Wakai, Y. Ito, M. Kojima et al., "Intake frequency of fish and serum levels of long-chain n-3 fatty acids: a cross-sectional study within the Japan Collaborative Cohort Study," Journal of Epidemiology, vol. 15, no. 6, pp. 211-218, 2005.

[209] L. K. Dennis, L. G. Snetselaar, B. J. Smith, R. E. Stewart, and M. E. C. Robbins, "Problems with the assessment of dietary fat in prostate cancer studies," American Journal of Epidemiology, vol. 160, no. 5, pp. 436-444, 2004.

[210] L. Hodson, C. M. Skeaff, and B. A. Fielding, "Fatty acid composition of adipose tissue and blood in humans and its use as a biomarker of dietary intake," Progress in Lipid Research, vol. 47, no. 5, pp. 348-380, 2008.

[211] N. C. Øverby, L. Serra-Majem, and L. F. Andersen, "Dietary assessment methods on n-3 fatty acid intake: a systematic review," The British Journal of Nutrition, vol. 102, supplement 1 , pp. S56-S63, 2009.

[212] L. Dahl, C. A. Mæland, and T. Bjørkkjær, "A short food frequency questionnaire to assess intake of seafood and n-3 supplements: validation with biomarkers," Nutrition Journal, vol. 10, no. 1, article 127, 2011.

[213] W. S. Harris and R. M. Thomas, "Biological variability of blood omega-3 biomarkers," Clinical Biochemistry, vol. 43, no. 3, pp. 338-340, 2010.

[214] M. H. Davidson, J. Johnson, M. W. Rooney, M. L. Kyle, and D. F. Kling, "A novel omega-3 free fatty acid formulation has dramatically improved bioavailability during a low-fat diet compared with omega-3-acid ethyl esters: the ECLIPSE (Epanova compared to Lovaza in a pharmacokinetic singledose evaluation) study," Journal of Clinical Lipidology, vol. 6, no. 6, pp. 573-584, 2012.

[215] W. S. Harris, S. A. Varvel, J. V. Pottala, G. R. Warnick, and J. P. McConnell, "Comparative effects of an acute dose of fish oil on omega-3 fatty acid levels in red blood cells versus plasma: implications for clinical utility," Journal of Clinical Lipidology, vol. 7, no. 5, pp. 433-440, 2013.

[216] E. Fasano, S. Serini, A. Cittadini, and G. Calviello, "LongChain n-3 PUFA against breast and prostate cancer: which are the appropriate doses for intervention studies in animals and humans?" Critical Reviews in Food Science and Nutrition, 2015.

[217] E. J. Freireich, E. A. Gehan, D. P. Rall, L. H. Schmidt, and H. E. Skipper, "Quantitative comparison of toxicity of anticancer agents in mouse, rat, hamster, dog, monkey, and man," Cancer Chemotherapy Reports, vol. 50, no. 4, pp. 219-244, 1966.

[218] P. Bougnoux, N. Hajjaji, M. N. Ferrasson, B. Giraudeau, C. Couet, and O. Le Floch, "Improving outcome of chemotherapy of metastatic breast cancer by docosahexaenoic acid: a phase II trial," British Journal of Cancer, vol. 101, no. 12, pp. 1978-1985, 2009. 
[219] L. D. Yee, J. L. Lester, R. M. Cole et al., “ $\omega-3$ fatty acid supplements in women at high risk of breast cancer have dose-dependent effects on breast adipose tissue fatty acid composition," The American Journal of Clinical Nutrition, vol. 91, no. 5, pp. 1185-1194, 2010.

[220] M. Yamashita, Y. Yamashita, T. Ando, J. Wakamiya, and S. Akiba, "Identification and determination of selenoneine, 2selenyl- $N_{\alpha}, N_{\alpha}, N_{\alpha}$-trimethyl-L-histidine, as the major organic selenium in blood cells in a fish-eating population on remote Japanese Islands," Biological Trace Element Research, vol. 156, no. 1-3, pp. 36-44, 2013.

[221] J. Dort, N. Leblanc, J. Maltais-Giguère, B. Liaset, C. H. Côté, and H. Jacques, "Beneficial effects of cod protein on inflammatory cell accumulation in rat skeletal muscle after injury are driven by its high levels of arginine, glycine, taurine and lysine," PLoS ONE, vol. 8, no. 10, Article ID e77274, 2013.

[222] R. Hosomi, M. Yoshida, and K. Fukunaga, "Seafood consumption and components for health," Global Journal of Health Science, vol. 4, no. 3, pp. 72-86, 2012.

[223] A. P. Simopoulos, "Genetic variants in the metabolism of omega- 6 and omega-3 fatty acids: their role in the determination of nutritional requirements and chronic disease risk," Experimental Biology and Medicine, vol. 235, no. 7, pp. 785-795, 2010.

[224] J. P. Vanden Heuvel, "Nutrigenomics and nutrigenetics of $\omega 3$ polyunsaturated fatty acids," Progress in Molecular Biology and Translational Science, vol. 108, pp. 75-112, 2012.

[225] M. Gago-Dominguez, J. E. Castelao, C.-L. Sun et al., "Marine n-3 fatty acid intake, glutathione $S$-transferase polymorphisms and breast cancer risk in post-menopausal Chinese women in Singapore," Carcinogenesis, vol. 25, no. 11, pp. 2143-2147, 2004.

[226] M. C. Stern, K. D. Siegmund, R. Corral, and R. W. Haile, "XRCC1 and XRCC3 polymorphisms and their role as effect modifiers of unsaturated fatty acids and antioxidant intake on colorectal adenomas risk," Cancer Epidemiology Biomarkers and Prevention, vol. 14, no. 3, pp. 609-615, 2005.

[227] E. M. Poole, J. Bigler, J. Whitton et al., "Genetic variability in prostaglandin synthesis, fish intake and risk of colorectal polyps," Carcinogenesis, vol. 28, no. 6, pp. 1259-1263, 2007.

[228] E. M. Poole, L. Hsu, L. Xiao et al., "Genetic variation in prostaglandin E2 synthesis and signaling, prostaglandin dehydrogenase, and the risk of colorectal adenoma," Cancer Epidemiology Biomarkers and Prevention, vol. 19, no. 2, pp. 547-557, 2010.

[229] M. C. Stern, L. M. Butler, R. Corral et al., "Polyunsaturated fatty acids, DNA repair single nucleotide polymorphisms and colorectal cancer in the Singapore Chinese Health Study," Journal of Nutrigenetics and Nutrigenomics, vol. 2, no. 6, pp. 273279, 2010.

[230] S. R. Porenta, Y.-A. Ko, S. B. Gruber et al., "Interaction of fatty acid genotype and diet on changes in colonic fatty acids in a Mediterranean diet intervention study," Cancer Prevention Research, vol. 6, no. 11, pp. 1212-1221, 2013. 

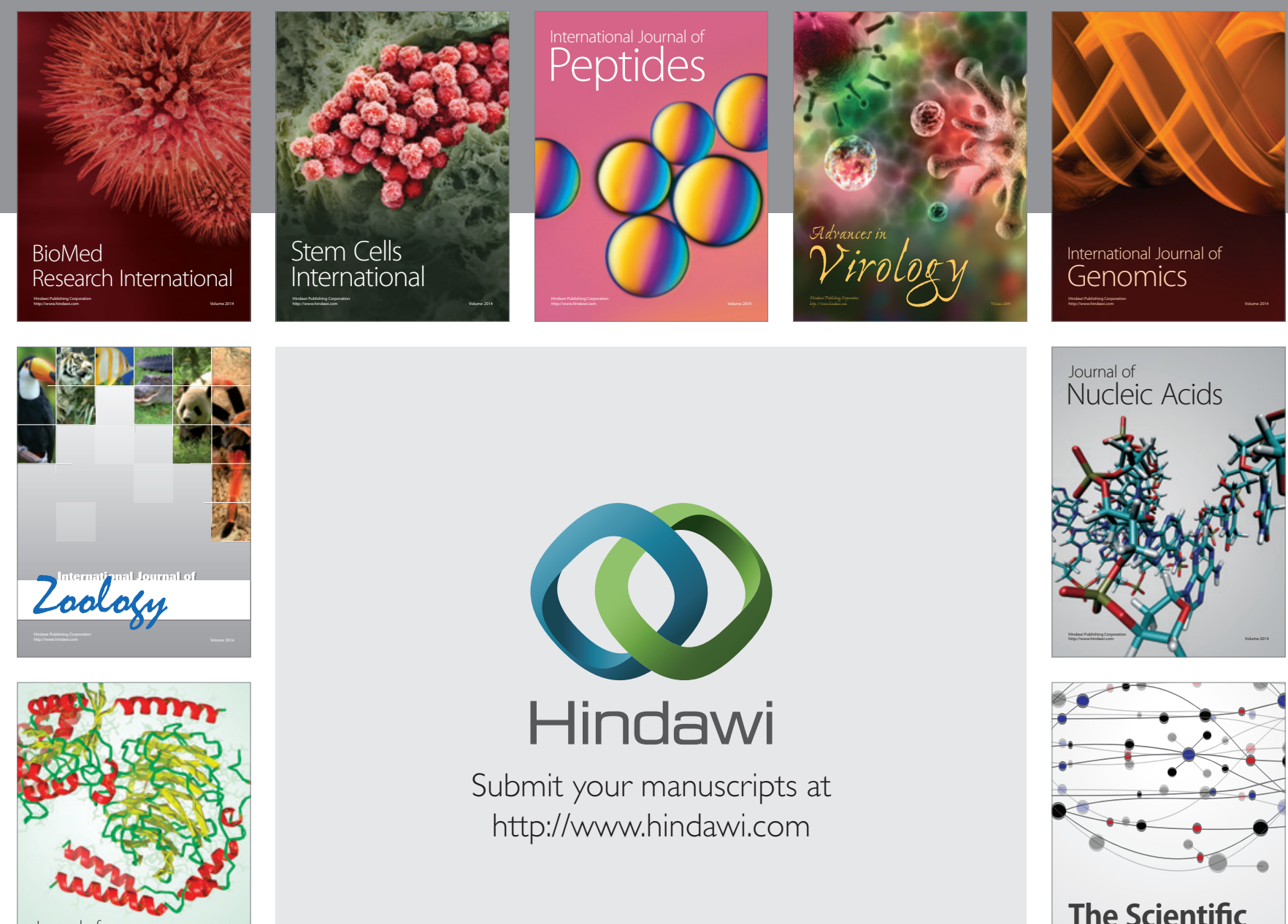

Submit your manuscripts at

http://www.hindawi.com

Journal of
Signal Transduction
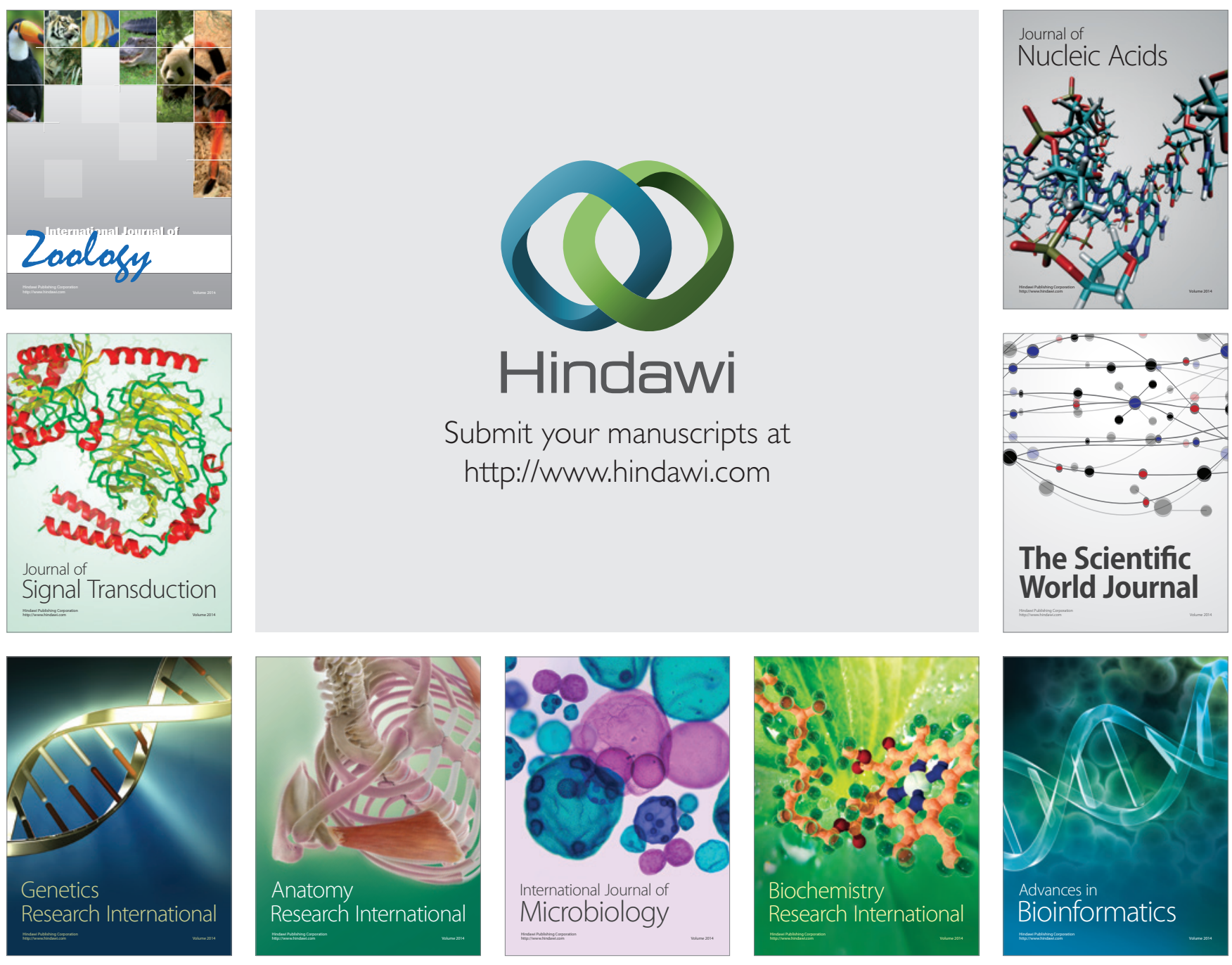

The Scientific World Journal
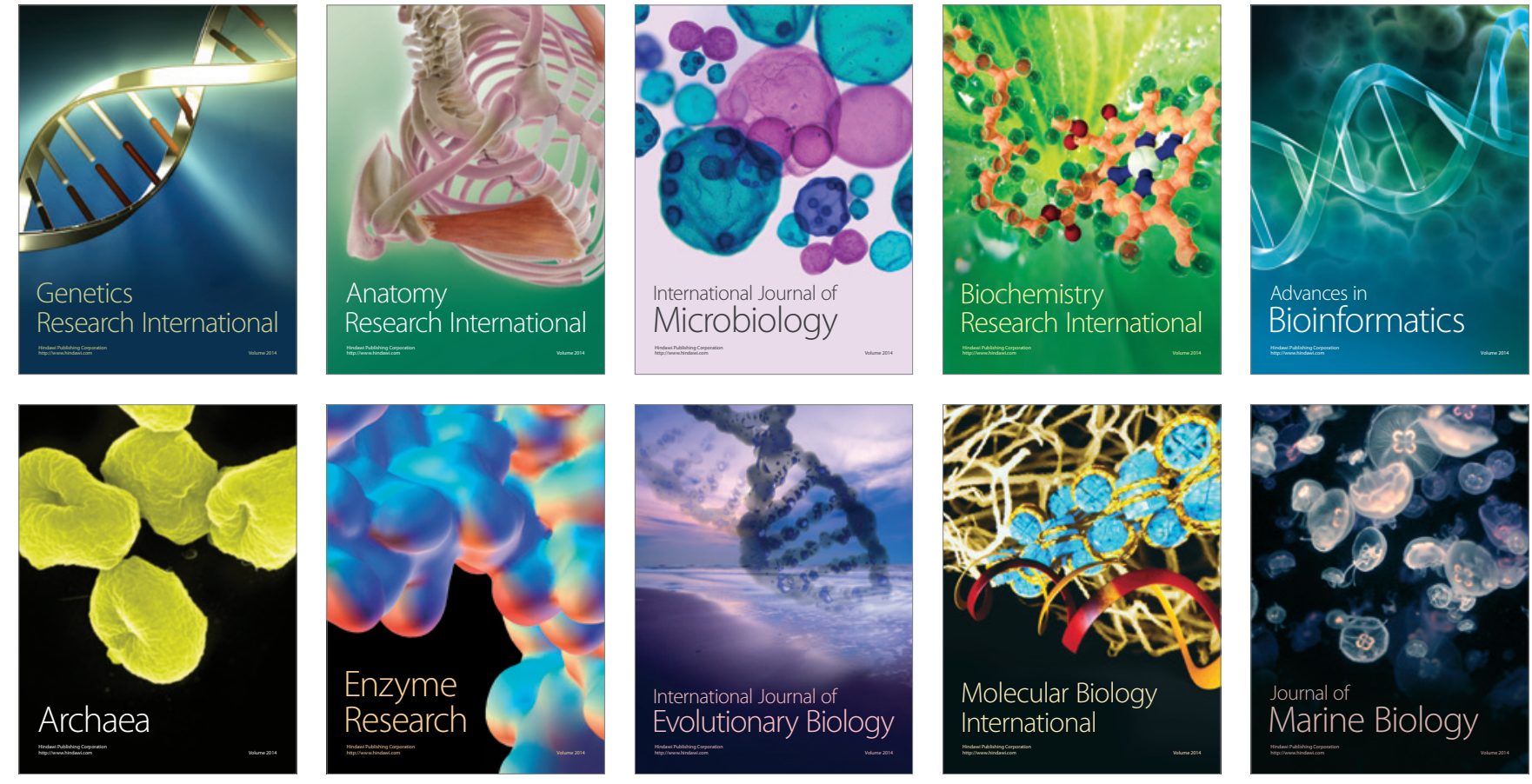